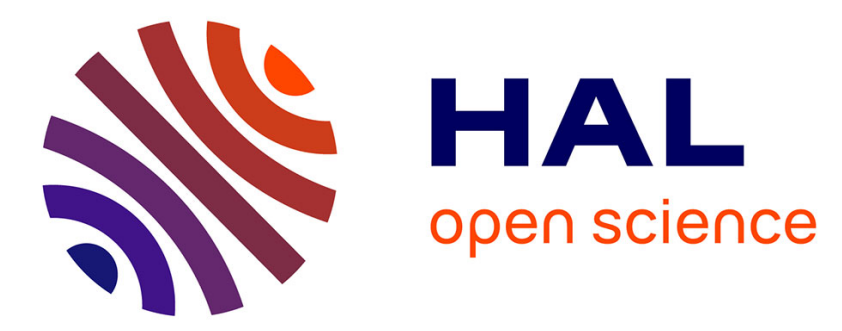

\title{
Structural study of polymorphism and thermal behavior of $\mathrm{CaZr}(\mathrm{PO} 4) 2$
}

Damien Bregiroux, Gilles Wallez, Karin Popa

\section{To cite this version:}

Damien Bregiroux, Gilles Wallez, Karin Popa. Structural study of polymorphism and thermal behavior of CaZr(PO4)2. Solid State Sciences, 2015, 41, pp.43-47. 10.1016/j.solidstatesciences.2015.02.004 . hal-01118111

\section{HAL Id: hal-01118111 \\ https://hal.sorbonne-universite.fr/hal-01118111}

Submitted on 23 Feb 2015

HAL is a multi-disciplinary open access archive for the deposit and dissemination of scientific research documents, whether they are published or not. The documents may come from teaching and research institutions in France or abroad, or from public or private research centers.
L'archive ouverte pluridisciplinaire HAL, est destinée au dépôt et à la diffusion de documents scientifiques de niveau recherche, publiés ou non, émanant des établissements d'enseignement et de recherche français ou étrangers, des laboratoires publics ou privés. 
Structural study of polymorphism and thermal behavior of $\mathrm{CaZr}\left(\mathrm{PO}_{4}\right)_{2}$

Damien Bregiroux ${ }^{1 *}$, Gilles Wallez ${ }^{2,3}$, and Karin Popa ${ }^{4}$

${ }^{1}$ Sorbonne Universités, UPMC Univ Paris 06, CNRS, Collège de France, Laboratoire de Chimie de la Matière Condensée de Paris, 11 place Marcelin Berthelot, 75005 Paris, France.

${ }^{2}$ Institut de Recherche de Chimie Paris (IRCP), CNRS - Chimie ParisTech - Paris Sciences et Lettres PSL UMR8247, 11 rue Pierre et Marie Curie, 75005 Paris, France

${ }^{3}$ Sorbonne Universités, UPMC Univ Paris 06

4 “Al.I. Cuza” University, Department of Chemistry, 11-Carol I Blvd., 700506 Iasi, Romania

*Corresponding author: damien.bregiroux@upmc.fr

Tel. : +33 (0)1 44271528

Fax. : +33(0)144271504 


\begin{abstract}
The crystal structure of $\mathrm{CaZr}\left(\mathrm{PO}_{4}\right)_{2}$ has been revised by ab initio Rietveld analysis of $\mathrm{X}$-ray powder diffraction data. At room temperature, $\mathrm{CaZr}\left(\mathrm{PO}_{4}\right)_{2}$ crystallizes in the orthorhombic space group $P n a 2_{1}(Z=4)$. Differential thermal analysis suggests a reversible second order transition at $1000^{\circ} \mathrm{C}$ confirmed by high temperature XRD analysis that brings out the existence of a high temperature form, very similar to the room temperature one, but more symmetrical (Pnma, $Z=4)$. Analysis of the crystal parameters evolution during heating reveals that $\mathrm{CaZr}\left(\mathrm{PO}_{4}\right)_{2}$ exhibits a quite low thermal expansion coefficient of $6.1110^{-6} \mathrm{~K}^{-1}$. This value stems from a combination of several mechanisms, including Coulombic repulsion and bridging oxygen rocking motion.
\end{abstract}

Keywords: Crystal structure; thermal expansion; calcium zirconium phosphate

\title{
Highlights:
}

Room temperature structure $\mathrm{CaZr}\left(\mathrm{PO}_{4}\right)_{2}$ was revised A high temperature form of $\mathrm{CaZr}\left(\mathrm{PO}_{4}\right)_{2}$ was described for the first time Thermal expansion of $\mathrm{CaZr}\left(\mathrm{PO}_{4}\right)_{2}$ was studied on the basis of the evolution of the crystal parameters evolution during heating 


\section{Introduction}

$M^{\mathrm{II}} M^{, \mathrm{IV}}\left(\mathrm{PO}_{4}\right)_{2}$ compounds $\left(M^{\mathrm{II}}=\mathrm{Cd}, \mathrm{Ca}, \mathrm{Sr}, \mathrm{Pb}, \mathrm{Ba} ; M^{\mathrm{IV}}=\mathrm{Ge}, \mathrm{Ti}, \mathrm{Mo}, \mathrm{Sn}, \mathrm{Hf}, \mathrm{Zr}, \mathrm{Pu}, \mathrm{Np}, \mathrm{U}\right.$, Th) are subject of intensive research since they are proved to be interesting as ionic conductors, dielectrics, catalysts, ion exchangers, luminescent materials and UV-emitting Xray phosphors [1-7]. They also find applications in the nuclear cycle, either as host matrices for actinide radwastes or, more recently, as products of the reaction of the spent nuclear fuel with tributyl phosphate during the reprocessing [8-22].

$M^{\mathrm{II}} M^{\text {,IV }}\left(\mathrm{PO}_{4}\right)_{2}$ can be classified according to their crystal structure. One can distinguish two main groups, depending on the cations size:

- $\quad$ The cheralite-type compounds, analogues of monazite $\mathrm{CePO}_{4}$, where trivalent $\mathrm{Ce}$ is replaced randomly by $M$ and $M^{\prime}$. The archetype, $\mathrm{CaTh}\left(\mathrm{PO}_{4}\right)_{2}$, also named brabantite, was described by Rose et al. in 1980 [23]. Cheralite compounds crystallize in the monoclinic $P 2_{1} / n$ space group $(Z=4)$ [24]. This structure consists of chains made up by alternating edges-linked irregular ninefold-coordinated $M / M^{\prime}$ cations and distorted tetrahedral phosphate groups. This structural form can be found for high radius $M^{\prime}$ cations (i.e. actinides).

- $\quad$ For smaller $M^{, I V}$ cations, like those of the $p$ - and $d$-blocks, most of the $M^{\mathrm{II}} M^{, \mathrm{IV}}\left(\mathrm{PO}_{4}\right)_{2}$ compounds crystallize in the yavapaiite-type structure (isotype of $\left.\mathrm{KFe}\left(\mathrm{SO}_{4}\right)_{2}\right)$, which consists of layers running parallel to the (001) plane built up of corner-connected $M \mathrm{O}_{6}$ octahedra and $\mathrm{PO}_{4}$ tetrahedra. The $M^{I I}$ cation takes place into the interlayer, in a ten-fold oxygen environment [25]. Several derivatives of this archetype, or "distorted yavapaiites" have been observed, according the $M^{I I}$ and $M^{, I V}$ cation size [26-28].

Nevertheless, some compositions exhibit a clearly different crystal structure, like $\mathrm{CaZr}\left(\mathrm{PO}_{4}\right)_{2}$, $\mathrm{PbSn}\left(\mathrm{PO}_{4}\right)_{2}$ and $\mathrm{SrNp}\left(\mathrm{PO}_{4}\right)_{2}[1,29,30]$. The structure of $\mathrm{CaZr}\left(\mathrm{PO}_{4}\right)_{2}$ was determined for the first time by Fukuda et al. from powder diffraction data [31]. The structure was found to be orthorhombic (space group $P 22_{1} 2_{1} 2_{1}, Z=4$ ). $\mathrm{Ca}$ and $\mathrm{Zr}$ cations are both sevenfold coordinated 
but are located in different sites, unlike in the cheralite structure. On the other hand, the structure is not a layered one, as observed for yavapaiite compounds. Within the $M^{\mathrm{II}} M^{, \mathrm{IV}}\left(\mathrm{PO}_{4}\right)_{2}$ family, $\mathrm{CaZr}\left(\mathrm{PO}_{4}\right)_{2}$ is the compound in which the best optical properties were observed [32]. For such applications, a perfect description of the crystal structure, including a very accurate knowledge of cations environment and atomic distances is required, especially for crystal field calculations. As described in the following sections, our XRD observations suggest that the crystal structure proposed by Fukuda et al. is not the most relevant one. In this paper, we propose a revision of the crystal structure of $\mathrm{CaZr}\left(\mathrm{PO}_{4}\right)_{2}$. A low and a high temperature forms are proposed. The mechanisms of the phase transition and the thermal expansion of the low temperature form are also described from the lattice thermal evolution during heating.

\section{Experimental}

\subsection{Synthesis and characterization}

$\mathrm{CaZr}\left(\mathrm{PO}_{4}\right)_{2}$ compounds were obtained from a conventional solid state route. Based on the previous work of Popa et al., a mixture of $\mathrm{CaCO}_{3}$ (Prolabo, 99.5\%), $\mathrm{ZrO}_{2}$ (Aldrich, 99.9\%) and 15 wt.\% excess of $\mathrm{NH}_{4} \mathrm{H}_{2} \mathrm{PO}_{4}$ (Aldrich, 99.99\%) were ground and fired slowly in air up to $1200^{\circ} \mathrm{C}$ for $10 \mathrm{~h}$ in a platinum crucible [33]. The thermal cycle was performed twice in order to avoid the presence of unreacted phases. Powder purity was checked by X-Ray powder diffraction. Thermal stability and possible phase transition were studied under air using a Setaram DTA-TG instrument. XRPD was performed on a Panalytical X'Pert Pro diffractometer with an incident-beam Ge monochromator, at $U=45 \mathrm{kV}$ and $I=40 \mathrm{~mA}$. The apparatus was equipped with an Anton Paar HTK 1200 N furnace for high temperature diffraction. The patterns for structural analysis were recorded over $8 \mathrm{~h}$ in the $8 \leq 2 \theta \leq 140^{\circ}$ range $\left(130^{\circ}\right.$ at high temperature), step $0.013^{\circ}$. For the measurement of the thermal expansion, 
the patterns were recorded at high temperature in the same range but over $1 \mathrm{~h}$. The Rietveld analyses were carried out with the Fullprof suite [34]. Structures were drawn using the VESTA software [35].

\subsection{Structure resolution}

Except for minor reflections ascribed to spurious NZP-like $\mathrm{Ca}_{0.5} \mathrm{Zr}_{2}\left(\mathrm{PO}_{4}\right)_{3}(<5 \%)$, the powder XRD pattern of the sample appears very similar to that reported by the ICDD file 732816 calculated from Fukuda's structural data. Nevertheless, while the $P 2{ }_{1} 2_{1} 2_{1}$ space group proposed by these authors supposes that systematic extinction only affects the $h 00,0 k 0$ and $00 l$ reflections with odd Miller indexes, clear hints of the presence of two glide mirrors are observed: a $c$ one perpendicular to Fukuda's cell edge $a$ and a $n$ one perpendicular to the $c$ edge. For instance, the relevant reflections $(0 k l, k=2 n+1$ and $h k 0, h+k=2 n+1$, barring overlapped ones) are extremely weak, respectively less than 0.1 and $0.6 \%$ in intensity in the ICDD file. From our own XRD pattern, those peaks (25 in the $0<2 \theta<80^{\circ}$ range) were all found to be non-observable. Likewise, the Rietveld analysis performed in Le Bail's (profile matching) mode with the symmorphic Pmmm space group resulted in a mean intensity of less than $0.1 \%$ for all of them. In Fukuda's axes setting, these conditions account either for acentric space group $P c 2_{1} n$ (Pna $2_{1}$ in standard setting) or for centric Pcmn (Pnma). A test of second harmonic generation with an incident YAG:Nd laser beam at $1060 \mathrm{~nm}$ was negative, thus no conclusion could be achieved on this basis.

The three most probable space groups $\left(P n a 2_{1}\right.$, Pnma, $\left.P 2_{1} 2_{1} 2_{1}\right)$ were considered for the refinement of the crystal structure at room temperature, termed $\alpha-\mathrm{CaZr}\left(\mathrm{PO}_{4}\right)_{2}$. Anisotropic thermal displacements were refined for the heavy $\mathrm{Ca}$ and $\mathrm{Zr}$ atoms, but all the oxygen atoms of a same $\mathrm{PO}_{4}$ tetrahedron were given the same isotropic factor. The anisotropic Lorentzian peaks broadening due to crystallites size effects was modeled using the spherical harmonic 
profile function. Spurious $\mathrm{Ca}_{0.5} \mathrm{Zr}_{2}\left(\mathrm{PO}_{4}\right)_{3}$ was treated as a secondary phase in the Rietveld analysis. For all the models, the refinements performed with "free" oxygen coordinates resulted in poorly realistic P-O distances (1.46-1.61 ̊), like in Fukuda's reported data (1.46$1.59 \AA$ A). Considering the covalency of the P-O bond that makes its length highly predictable in a monophosphate $(1.54 \AA$ ) , soft constraints were applied on these distances.

\section{Results and discussion}

\subsection{Crystal structure of the room-temperature form $\alpha$-CaZr(PO $\left.\mathrm{P}_{4}\right)_{2}$}

The following discussion deals mainly with the determination of the space group of the roomtemperature form. This point is pretty delicate, on the one hand because the two hemihedral groups $\left(P n a 2_{1}\right.$ and $\left.P 2_{1} 2_{1} 2_{1}\right)$ are subgroups of the holohedral one $(P n m a)$, on the other hand, because the three structural models only show minor differences after refinement. As shown by Fukuda, the edge-connected $\mathrm{CaO}_{7}$ and $\mathrm{ZrO}_{7}$ polyhedra form linear chains. The $\mathrm{P} \mathrm{O}_{4}$ tetrahedron shares two opposite edges with $\mathrm{CaO}_{7}$ polyhedra and the $\mathrm{P}_{2} \mathrm{O}_{4}$ tetrahedra shares an edge with a $\mathrm{ZrO}_{7}$. Setting the floating $z \mathrm{Zr}$ coordinate in the polar $P n a 2_{1}$ space group at the same value as in the $P 2{ }_{1} 2_{1} 2_{1}$ model, the atomic positions appear only faintly distant between the two hemihedral models (Zr: $0.02 \AA$; Ca: $0.03 \AA$; P1: $0.07 \AA$; P2: $0.01 \AA$; distances between oxygen positions are not significant because of the lower weight of these atoms and the application of soft constraints). The reliability factors are not significantly different $\left(R_{\mathrm{Bragg}}\right.$ $=0.0308$ for $P n a 2_{1}, 0.0324$ for $P 2_{1} 2_{1} 2_{1}$ ), but the systematic absences (see Experimental) account for the $P n a 2_{1}$ solution rather than for the $P 2{ }_{1} 2_{1} 2_{1}$ one, defended by Fukuda et al. The choice between the $P n a 2_{1}$ and Pnma space groups (with $b-c$ axes permutation) can hardly be made on the sole basis of the reliability factors $\left(R_{\mathrm{Bragg}}=0.0308\right.$ and 0.0387 respectively $)$ because of the lesser number of intensity-dependent parameters in the latter form ( 52 and 35 respectively). Indeed, the decision hangs on the existence of the $m$ mirror. In the holohedral 
form, all the cations and half of the oxygen anions are supposed to occupy this special (1/4 or 3/4) position. Once again, the variations of the cations positions are faint (Zr: $0.00 \AA$; $\mathrm{Ca}: 0.01$ $\AA$; P1: $0.06 \AA$; P2: $0.04 \AA$ ), but in this case the shifts of the oxygen anions involved in edgesharing between $\mathrm{Ca}$ and $\mathrm{P} 1$ on the one hand $(0.21$ and $0.15 \AA)$ and $\mathrm{Zr}$ and $\mathrm{P} 2$ on the other hand $(0.27$ and $0.25 \AA)$ are significant enough to be taken into account. Actually, these shared edges, ideally parallel to the $b$-axis in the Pnma cell, exhibit a clear zig-zag geometry in the $P n a 2_{1}$ one as a result of the distortion of the $\mathrm{PO}_{4}$ tetrahedra (Fig. 1. lower view). The same distortion is observed in Fukuda's structure. Besides, the O23-P2-O24 $\left(96.5(8)^{\circ}\right)$ angle corresponding to the shared edge between $\mathrm{Zr}$ and $\mathrm{P} 2$ is low, because of the Coulombic intercations repulsion. As will be shown in the following, these structural features play a role in the peculiar thermal expansion of the compound. Main acquisition and refinement parameters are reported in Table 1, atomic coordinates in Table 2 and bond lengths in Table 3. The crystal structure of $\alpha-\mathrm{CaZr}\left(\mathrm{PO}_{4}\right)_{2}$ is drawn in Fig. 1. The resulting final Rietveld plots are shown in Fig. 2.

\subsection{Phase transition and high-temperature form $\beta$-CaZr $\left(\mathrm{PO}_{4}\right)_{2}$}

$\mathrm{CaZr}\left(\mathrm{PO}_{4}\right)_{2}$ appears to be stable up to $1200^{\circ} \mathrm{C}$ and melts between $1300^{\circ} \mathrm{C}$ and $1400^{\circ} \mathrm{C}$. No peak can be observed by conventional differential thermal analysis between $1000^{\circ} \mathrm{C}$ and $1200^{\circ} \mathrm{C}$, suggesting that the $\alpha$ to $\beta$ transition could be a reversible second order phase transition. Because no significant variation was observed in the diffraction pattern above this temperature, we refined the structure again in the $P n a 2_{1}$ space group (Tables 1-2). This time, the cations positions turned out to be so faintly shifted $(<0.004 \AA$, lower than the estimated standard deviations) that they could be considered as located right on the $m$-mirror of the Pnma setting. This high-temperature form will be termed $\beta-\mathrm{CaZr}\left(\mathrm{PO}_{4}\right)_{2}$ in the following. As shown by Table 3 , its crystal structure is very similar to that of $\alpha-\mathrm{CaZr}\left(\mathrm{PO}_{4}\right)_{2}$. Therefore, the 
$\alpha-\beta$ transition appears as a typical second-order phenomenon in agreement with its thermal signature.

\subsection{Thermal expansion}

The relative variation with temperature of the cell parameters and $\mathrm{Ca}-\mathrm{P}$ and $\mathrm{Zr}-\mathrm{P}$ distances of $\alpha-\mathrm{CaZr}\left(\mathrm{PO}_{4}\right)_{2}$ is plotted on Fig. 3.

Thermal expansion was calculated according to the following linear equation:

$$
\alpha_{x}=\frac{d x}{x_{0}} \frac{1}{d T}
$$

Values are reported on Table 4. The mean relative linear thermal expansion (1) was determined by dividing the volume expansion by 3 .

The resulting relative linear thermal expansion appears to be quite low compared to that of the most common oxides $\left(6.11\right.$ vs. 7-8, 8-12, 9-12 $10^{-6} . \mathrm{K}^{-1}$ for alumina, zirconia, magnesia, respectively). Results also show that thermal expansion is rather anisotropic $\left(\Delta \alpha=6.710^{-6} . \mathrm{K}^{-}\right.$

$\left.{ }^{1}\right)$. $\alpha-\mathrm{CaZr}\left(\mathrm{PO}_{4}\right)_{2}$ mostly expands along the $a$-axis. $b$ - and $c$ - axes exhibit similar thermal expansion coefficients. Comparison of thermal behavior of $\mathrm{CaZr}\left(\mathrm{PO}_{4}\right)_{2}$ with that of some other phosphates (Table 5) reveals that this compound exhibits a interesting combination between low value and moderate anisotropy of thermal expansion. Associated with a good thermal stability (up to $1200{ }^{\circ} \mathrm{C}$ ), $\mathrm{CaZr}\left(\mathrm{PO}_{4}\right)_{2}$ appears to be an interesting material for applications that require a good dimensional stability with temperature.

The thermal expansion behavior of $\mathrm{CaZr}\left(\mathrm{PO}_{4}\right)_{2}$ can be explained regarding the polyhedral connections (see Fig. 1). In this structure, different thermal expansion mechanisms can be observed, all described by Sleight on other materials [42]. Along the $a$ axis, strong Coulombic repulsion occurs between edge-sharing $\mathrm{Zr}^{4+}$ and $\mathrm{P}^{5+}$ cations since the $\mathrm{Zr}-\mathrm{P} 2$ (a) distance are short and oxygen atoms screening effect is low, resulting in a strong thermal expansion of the 
Zr-P2(a) distance (Figs. 1 and 3, Table 4). On the opposite, when polyhedra are cornerconnected, the oxygen shared by the $\mathrm{ZrO}_{7}$ and $\mathrm{P} 2(\mathrm{~b}) \mathrm{O}_{4}$ polyhedra oscillates within an ellipsoid oriented roughly perpendicular to the $\mathrm{Zr}-\mathrm{O}-\mathrm{P}$ axis. Since the $\mathrm{Zr}-\mathrm{O}$ and $\mathrm{P}-\mathrm{O}$ bonds are strong enough to present negligible thermal expansion, the transverse motion of oxygen pulls the cations closer together. This so-called "rocking effect" can explain the quite negligible thermal expansion of the $\mathrm{Zr}-\mathrm{P} 2$ (b) distance. $\mathrm{CaO}_{7}$ polyhedra are only linked by edge to the two $\mathrm{PO}_{4}$ tetrahedra. The Coulombic repulsion is weaker than in the case of $\mathrm{Zr}^{4+}$ because of the lower valency and higher ionic radius of $\mathrm{Ca}^{2+}$ leading to a lower thermal expansion. Note that the shortest Ca-P distance (i.e. Ca-P1(a)) shows the highest thermal expansion coefficient. The combination of these phenomena leads to a moderate thermal expansion along the $a$ axis. The Coulombic repulsion between cations along the $a$ axis has a consequence on the thermal expansion along $c$. The oxygen atoms involved in the edges perpendicular to the $M$-P bonds are getting closer, leading to a low thermal expansion along $c$ (Fig. 4). Along $b$, the structure presents several connections by corners, especially between $\mathrm{CaO}_{7}$ and $\mathrm{PO}_{4}$. This results in a very low thermal expansion along this direction by oxygen rocking effect.

\section{Conclusion}

A revised structure of $\mathrm{CaZr}\left(\mathrm{PO}_{4}\right)_{2}$ has been proposed. For the first time, the existence of a high temperature form of this compound has been highlighted. These structures are strongly different to that of most of the other compounds of the $M^{\mathrm{II}} M^{\text {,IV }}\left(\mathrm{PO}_{4}\right)_{2}$ family (yavapaiite and cheralite). Analysis of the crystal parameters evolution during heating reveals that $\mathrm{CaZr}\left(\mathrm{PO}_{4}\right)_{2}$ exhibits a quite low thermal expansion coefficient of $6.1110^{-6} \mathrm{~K}^{-1}$, suggesting that this compounds could find applications when dimensional stability is required. 


\section{Acknowledgements}

The authors are grateful to Guillaume Le for his enthusiastic participation in the synthesis experimentations. K.P. acknowledges La Mairie de Paris for the "Research in Paris' 20102011 fellowship.

\section{Appendix A. Supplementary data}

Supplementary data related to this article:

- $\quad$ CIF and CheckCIF files of $\alpha-\mathrm{CaZr}\left(\mathrm{PO}_{4}\right)_{2}$

- $\quad$ CIF and CheckCIF files of $\beta-\mathrm{CaZr}\left(\mathrm{PO}_{4}\right)_{2}$

- $\quad$ CSD number of $\alpha-\mathrm{CaZr}\left(\mathrm{PO}_{4}\right)_{2}: 428800$

- $\quad$ CSD number of $\beta-\mathrm{CaZr}\left(\mathrm{PO}_{4}\right)_{2}: 428801$

- $\quad$ Peak list file of $\alpha-\mathrm{CaZr}\left(\mathrm{PO}_{4}\right)_{2}$

\section{References}

[1] E. Morin, G. Wallez, S. Jaulmes, J.C. Couturier, M. Quarton, J. Solid State Chem.137 (1998) 283.

[2] F. Tudorache, K. Popa, L. Mitoseriu, N. Lupu, D. Bregiroux, G. Wallez, J. Alloys Compd $509(2011) 9127$

[3] K. Fukuda, A. Moriyama, T. Iwata, J. Solid State Chem.178 (2005) 2144.

[4] G. Blasse, G.J. Dirksen, Chem. Phys. Lett. 62 (1979) 19.

[5] C.R. Miao, C.C. Torardi, J. Solid State Chem.155 (2000) 229.

[6] Z.J. Zhang, J.L. Yuan, X.J. Wang, D.B. Xiong, H.H. Chen, J.T. Zhao, Y.B. Fu, Z.M. Qi, G.B. Zhang, C.S. Shi, J. Phys. D: Appl. Phys. 40 (2007) 1910.

[7] W.-L. Zhang, C.-S. Lin, Z.-Z. He, H. Zhang, Z.-Z. Luo, W.-D. Cheng, CrystEngComm 15 (2013) 7089. 
[8] I.W. Donald, Waste immobilization in glass and ceramic based hosts. Radioactive, toxic and hasardous wastes, Wiley, Chichester, UK, 2010.

[9] W.C. Overstreet, U.S. Geological Survey Professional Paper 530 (1967) 1.

[10] C.M. Gramaccioli, T.V. Segalstad, Am. Mineral. 63 (1978) 757.

[11] B.C. Sales, C.W. White, L.A. Boatner, Nucl.Chem. Waste Managem.4 (1983) 266.

[12] L.A. Boatner, G.W. Beall, M.M. Abraham, C.B. Finch, P.G. Hurray, M. Rappaz, p. 289 in Scientific Basis for Nuclear Waste Management, Vol. 2, Edited by C.J.M. Northrup Jr. Material Research Society, Warrendale, PA, USA, New York, 1980.

[13] L.A. Boatner, B.C. Sales, in Radioactive waste forms for the future, Edited by W. Lutze, R.C. Ewing, North Holland, Amsterdam (1988) 495.

[14] A. Meldrum, L.A. Boatner, W.J. Weber, R.C. Ewing, Geochim. Cosmochim. Acta 62 (1998) 2509.

[15] O. Terra, N. Clavier, N. Dacheux, R. Podor, New J. Chem. 27 (2003) 957.

[16] R.C. Ewing, Progr. Nucl. Energy 49 (2007) 635.

[17] D. Olander, J. Nucl. Mater. 389 (2009) 1.

[18] H. Schlenz, J. Heuser, A. Neumann, Z. Kristallogr 228 (2013) 113.

[19] N. Dacheux, N. Clavier, R. Podor, Am. Mineral. 98 (2013) 833.

[20] R.L. Murray, K.E. Holbert, chap. 23: Radioactive Waste Disposal, in « Nuclear Energy » (7th edition), Elsevier, 2014, 395-426.

[21] O. Terra, N. Dacheux, F. Audubert, R. Podor, J. Nucl. Mater. 352 (2006) 224.

[22] E. Veilly, E. du Fou de Kerdaniel, J. Roques, N. Dacheux, N. Clavier, Inorg. Chem. 47 (2008) 10971.

[23] D. Rose, Neues Jahr. Mineral. Monat.6 (1980) 247.

[24] G.W. Beall, L.A. Boatner, D.F. Mullica, W.O. Milligan, J. Inorg. Nucl. Chem. 43 (1981) 101. 
[25] E.J. Graeber, A. Rosenzweig, Amer. Min. 56 (1971) 1917.

[26] D. Bregiroux, K. Popa, R. Jardin, P.E. Raison, G. Wallez, M. Quarton, M. Brunelli, C.

Ferrero, R. Caciuffo, J. Solid State Chem. 182 (2009) 1115.

[27] K. Popa, G. Wallez, D. Bregiroux, P. Loiseau, J. Solid State Chem. 184 (2011) 2629.

[28] G. Wallez, D. Bregiroux, K. Popa, P.E. Raison, C. Apostolidis, P. Lindqvist-Reis, R.J.M. Konings, A.F. Popa, Eur. J. Inorg. Chem. (2011) 110.

[29] K. Fukuda, K. Fukutani, Powder Diffr. 18 (2003) 296.

[30] K. Popa, G. Wallez, P.E. Raison, D. Bregiroux, C. Apostolidis, P. Lindqvist-Reis, R.J.M. Konings, Inorg. Chem. 49 (2010) 6904.

[31] K. Fukuda, K. Fukutani, Powder Diffr. 18(4) (2003) 296.

[32] J.-C. Zhang, Y.-Z. Long, H.-D. Zhang, B. Sun, W.-P. Han, X.-Y. Sun, J. Mater. Chem. C, 2 (2014) 312.

[33] K. Popa, R.J.M. Konings, P. Boulet, D. Bouëxière, A.F. Popa, Thermochim. Acta 436 (2005) 51.

[34] J. Rodriguez-Carvajal, FULLPROF.2k : Rietveld, profile matching and integrated intensity refinement of X-ray and neutron data, V 1.9c, Laboratoire Léon Brillouin, CEA, Saclay, France, 2001.

[35] K. Momma, F. Izumi, J. Appl. Crystallogr., 44 (2011) 1272.

[36] N.E. Breese, M. O'Keeffe, Acta Cryst. B47 (1991) 192.

[37] A.I. Orlova, D.V. Kemenov, S.G. Samoilov, G.N. Kazantsev, V.I. Pet'kov, Inorg. Mater., $36(2000) 830$.

[38] D. Bregiroux, F. Audubert, E. Champion, D. Bernache-Assollant, Mater. Lett. 57 (2003) 3526.

[39] T. Tonegawa, T. Ikoma, Y. Suetsugu, N. Igawa, Y. Matsushita, T. Yoshioka, N.

Hanagata, J. Tanaka, Mater. Sci. Eng. B, 173 (2010) 171. 
[40] L. Perrière, D. Bregiroux, B. Naitali, F. Audubert, E. Champion, D.S. Smith, D. Bernache-Assollant, J.Eur. Ceram. Soc. 27 (2007) 3207.

[41] G. Wallez, D. Bregiroux, M. Quarton, J. Solid State Chem. 181 (2008) 1413.

[42] A.W. Sleight, Inorg. Chem. 37 (1998) 2854. 


\section{Tables caption}

\section{Table 1}

Main acquisition, refinement and lattice data for $\alpha$ - and $\beta-\mathrm{CaZr}\left(\mathrm{PO}_{4}\right)_{2}$.

\section{Table 2}

Atomic positions and thermal factors for $\alpha$ - and $\beta-\mathrm{CaZr}\left(\mathrm{PO}_{4}\right)_{2}$.

\section{Table 3}

Bond lengths in $\alpha$ - and $\beta-\mathrm{CaZr}\left(\mathrm{PO}_{4}\right)_{2}$ (in $\AA$ ).

\section{Table 4}

Thermal expansion in $\alpha-\mathrm{CaZr}\left(\mathrm{PO}_{4}\right)_{2}$.

\section{Table 5}

Comparison of thermal expansion of $\mathrm{CaZr}\left(\mathrm{PO}_{4}\right)_{2}$ with some other phosphates 


\section{Figures caption}

Fig. 1. Views of the structure of $\alpha-\mathrm{CaZr}\left(\mathrm{PO}_{4}\right)_{2}$

Fig. 2. Rietveld plots for $\alpha-\mathrm{CaZr}\left(\mathrm{PO}_{4}\right)_{2}$ and $\beta-\mathrm{CaZr}\left(\mathrm{PO}_{4}\right)_{2}: y_{\text {obs }}$ (dots), $y_{\text {calc }}$ (solid, upper), $y_{\text {obs }}{ }^{-}$ $y_{\text {calc }}$ (solid, lower), Bragg positions (bars)

Fig. 3. Thermal evolution of the cell parameters (a) and Ca-P and Zr-P distances (b, see Fig. 1. for atoms nomenclature)

Fig. 4. Coulombic repulsions between cations lead to high thermal expansion along $a$ and low thermal expansion along $c$ 


\section{Table 1}

Main acquisition, refinement and lattice data for $\alpha$ - and $\beta-\mathrm{CaZr}\left(\mathrm{PO}_{4}\right)_{2}$.

\begin{tabular}{|c|c|c|}
\hline Apparatus & \multicolumn{2}{|l|}{ Panalytical X'Pert Pro } \\
\hline Anode, monochromator & \multicolumn{2}{|l|}{ CuK $\alpha 1(40 \mathrm{kV}, 45 \mathrm{~mA}), \mathrm{Ge}(111)$} \\
\hline Form & $\alpha-\mathrm{CaZr}\left(\mathrm{PO}_{4}\right)_{2}$ & $\beta-\mathrm{CaZr}\left(\mathrm{PO}_{4}\right)_{2}$ \\
\hline Temperature & $20^{\circ} \mathrm{C}$ & $1200{ }^{\circ} \mathrm{C}$ \\
\hline Scan range, step, time & $8.00 \leq 2 \theta \leq 140.00^{\circ}, 0.013^{\circ}, 8 \mathrm{~h}$ & $8.00 \leq 2 \theta \leq 130.00^{\circ}, 0.013^{\circ}, 8 \mathrm{~h}$ \\
\hline Measured reflections & 626 & 576 \\
\hline Intensity / profile parameters & $52 / 14$ & $35 / 14$ \\
\hline Reliability factors & $\begin{array}{l}R_{P}=0.012 \\
R_{W P}=0.018 \\
R_{\text {Bragg }}=0.035 \\
\chi^{2}=8.2\end{array}$ & $\begin{array}{l}R_{P}=0.15 \\
R_{W P}=0.20 \\
R_{\text {Bragg }}=0.073 \\
\chi^{2}=6.4\end{array}$ \\
\hline System, space group & orthorhombic, Pna2 $_{1}$ (33) & orthorhombic, Pnma (62) \\
\hline Cell parameters, volume & $\begin{array}{l}a=6.2330(2) \AA \\
b=14.4852(5) \AA \\
c=6.7213(3) \AA \\
V=606.84(7) \AA^{3}\end{array}$ & $\begin{array}{l}a=6.3125(2) \AA\left(=a_{\alpha}\right) \\
b=6.7512(2) \AA\left(=c_{\alpha}\right) \\
c=14.5537(4) \AA\left(=b_{\alpha}\right) \\
V=620.23(6) \AA^{3}\end{array}$ \\
\hline Formula per cell / calc. density & $4 / 3.52$ & $4 / 3.44$ \\
\hline
\end{tabular}




\section{Table 2}

Atomic positions and thermal factors for $\alpha$ - and $\beta-\mathrm{CaZr}\left(\mathrm{PO}_{4}\right)_{2}$.

\begin{tabular}{|c|c|c|c|c|c|c|c|c|}
\hline & \multicolumn{4}{|c|}{$\alpha-\mathrm{CaZr}\left(\mathrm{PO}_{4}\right)_{2}$} & \multicolumn{4}{|c|}{$\beta-\mathrm{CaZr}\left(\mathrm{PO}_{4}\right)_{2}$} \\
\hline Atom & $x$ & $y$ & $z$ & $B^{*}\left(\AA^{2}\right)$ & $x$ & $y$ & $z$ & $B^{*}\left(\AA^{2}\right)$ \\
\hline $\mathrm{Ca}$ & $0.5492(2)$ & $0.3518(1)$ & $0.256(2)$ & $1.74(4)$ & $0.5466(5)$ & $1 / 4$ & $0.3534(3)$ & $3.82(9)$ \\
\hline $\mathrm{Zr}$ & $0.8239(1)$ & $0.3907(1)$ & 0.75 & $1.61(1)$ & $0.8340(2)$ & $3 / 4$ & $0.3896(1)$ & $2.07(3)$ \\
\hline $\mathrm{P} 1$ & $0.5459(2)$ & $0.1151(1)$ & $0.2435(4)$ & $2.05(6)$ & $0.5385(5)$ & $1 / 4$ & $0.1146(3)$ & $2.26(8)$ \\
\hline O11 & $0.6996(6)$ & $0.0306(2)$ & $0.244(4)$ & $1.24(6)$ & $0.687(1)$ & $1 / 4$ & $0.0292(5)$ & $3.4(1)$ \\
\hline $\mathrm{O} 12$ & $0.6784(7)$ & $0.2051(2)$ & $0.238(3)$ & " & $0.681(1)$ & $1 / 4$ & $0.2001(5)$ & " \\
\hline O13** & $0.396(2)$ & $0.1194(7)$ & $0.425(2)$ & “" & $0.3901(8)$ & $0.4308(7)$ & $0.1119(5)$ & " \\
\hline O14** & $0.389(2)$ & $0.1043(6)$ & $0.067(2)$ & “" & & & & \\
\hline $\mathrm{P} 2$ & $0.1313(2)$ & $0.8533(1)$ & $0.2480(4)$ & $2.16(6)$ & $0.1281(5)$ & $1 / 4$ & $0.8520(2)$ & $2.5(1)$ \\
\hline $\mathrm{O} 21$ & $0.1728(7)$ & $0.7493(2)$ & $0.268(2)$ & $1.43(7)$ & $0.169(1)$ & $1 / 4$ & $0.7482(4)$ & $3.5(1)$ \\
\hline $\mathrm{O} 22$ & $0.3425(5)$ & $0.9078(3)$ & $0.259(3)$ & $"$ & $0.339(1)$ & $1 / 4$ & $0.9037(6)$ & $"$ \\
\hline $\mathrm{O} 23 * *$ & $-0.014(2)$ & $0.8730(6)$ & $0.428(1)$ & "“ & $-0.146(8)$ & $0.4196(8)$ & $0.8815(5)$ & “" \\
\hline $\mathrm{O} 24 * *$ & $-0.016(2)$ & $0.8970(5)$ & $0.091(1)$ & “" & & & & \\
\hline
\end{tabular}

* given values are $B_{\text {iso }}$ for oxygen and phosphorus; $B_{e q}$ for calcium and zirconium. For $B_{a n i s o}$, see supplementary material ** atoms $\mathrm{O} 13$ and $\mathrm{O} 14$ of $\alpha-\mathrm{CaZr}\left(\mathrm{PO}_{4}\right)_{2}$ merge into a single atom in the $\beta$-form, idem for $\mathrm{O} 23$ and $\mathrm{O} 24$ 


\section{Table 3}

Bond lengths in $\alpha$ - and $\beta-\mathrm{CaZr}\left(\mathrm{PO}_{4}\right)_{2}$ (in $\AA$ ).

\begin{tabular}{|l|l|l|l|l|l|}
\hline Bond & $\alpha-\mathrm{CaZr}\left(\mathrm{PO}_{4}\right)_{2}$ & $\beta-\mathrm{CaZr}\left(\mathrm{PO}_{4}\right)_{2}$ & Bond & $\alpha-\mathrm{CaZr}\left(\mathrm{PO}_{4}\right)_{2}$ & $\beta-\mathrm{CaZr}\left(\mathrm{PO}_{4}\right)_{2}$ \\
\hline Ca-O11 & $2.766(4)$ & $2.842(9)$ & $\mathrm{Zr}-\mathrm{O} 22$ & $2.095(3)$ & $2.073(7)$ \\
\hline Ca-O12 & $2.275(4)$ & $2.387(9)$ & $\mathrm{Zr}-\mathrm{O} 23$ & $2.287(9)$ & $2.322(6)$ \\
\hline Ca-O12 & $2.457(5)$ & $2.435(9)$ & $\mathrm{Zr}-\mathrm{O} 24$ & $2.20(1)$ & “ \\
\hline Ca-O13 & $2.48(1)$ & $2.539(6)$ & $\mathrm{P} 1-\mathrm{O} 11$ & $1.553(4)$ & $1.556(9)$ \\
\hline Ca-O14 & $2.55(1)$ & $“$ & $\mathrm{P} 1-\mathrm{O} 12$ & $1.545(4)$ & $1.536(9)$ \\
\hline Ca-O23 & $2.23(1)$ & $2.276(6)$ & $\mathrm{P} 1-\mathrm{O} 13$ & $1.54(1)$ & $1.539(5)$ \\
\hline Ca-O24 & $2.35(1)$ & $“$ & $\mathrm{P} 1-\mathrm{O} 14$ & $1.54(1)$ & “ \\
\hline Zr-O11 & $2.033(3)$ & $2.035(7)$ & $\mathrm{P} 2-\mathrm{O} 21$ & $1.533(3)$ & $1.532(7)$ \\
\hline Zr-O13 & $2.23(1)$ & $2.184(5)$ & $\mathrm{P} 2-\mathrm{O} 22$ & $1.536(4)$ & $1.530(8)$ \\
\hline Zr-O14 & $2.17(1)$ & $“$ & $\mathrm{P} 2-\mathrm{O} 23$ & $1.537(9)$ & $1.519(6)$ \\
\hline Zr-O21 & $2.032(3)$ & $2.006(6)$ & $\mathrm{P} 2-\mathrm{O} 24$ & $1.538(9)$ & “ \\
\hline
\end{tabular}

Bond valence sums (v.u.) from [36]: $\mathrm{Ca}: 2.12(\alpha), 1.99(\beta)$; $\mathrm{Zr:} 4.06(\alpha), 4.06(\beta)$; for O-P-O angles, see supplementary material 


\section{Table 4}

Thermal expansion in $\alpha-\mathrm{CaZr}\left(\mathrm{PO}_{4}\right)_{2}$.

\begin{tabular}{|l|l|l|l|}
\hline Parameter & $\alpha\left(10^{-6} \cdot \mathrm{K}^{-1}\right)$ & Distance & $\alpha\left(10^{-6} \cdot \mathrm{K}^{-1}\right)$ \\
\hline$a$ & 10.3 & Zr-P2(a) & 16.4 \\
\hline$b$ & 4.1 & Zr-P2(b) & 0.6 \\
\hline$c$ & 3.8 & Ca-P1(a) & 13.9 \\
\hline$l$ & 6.1 & Ca-P1(b) & 5.9 \\
\hline
\end{tabular}

Note that P1(a)/P1(b) and P2(a)/P2(b) refer to the same atom P1 and P2, respectively. 

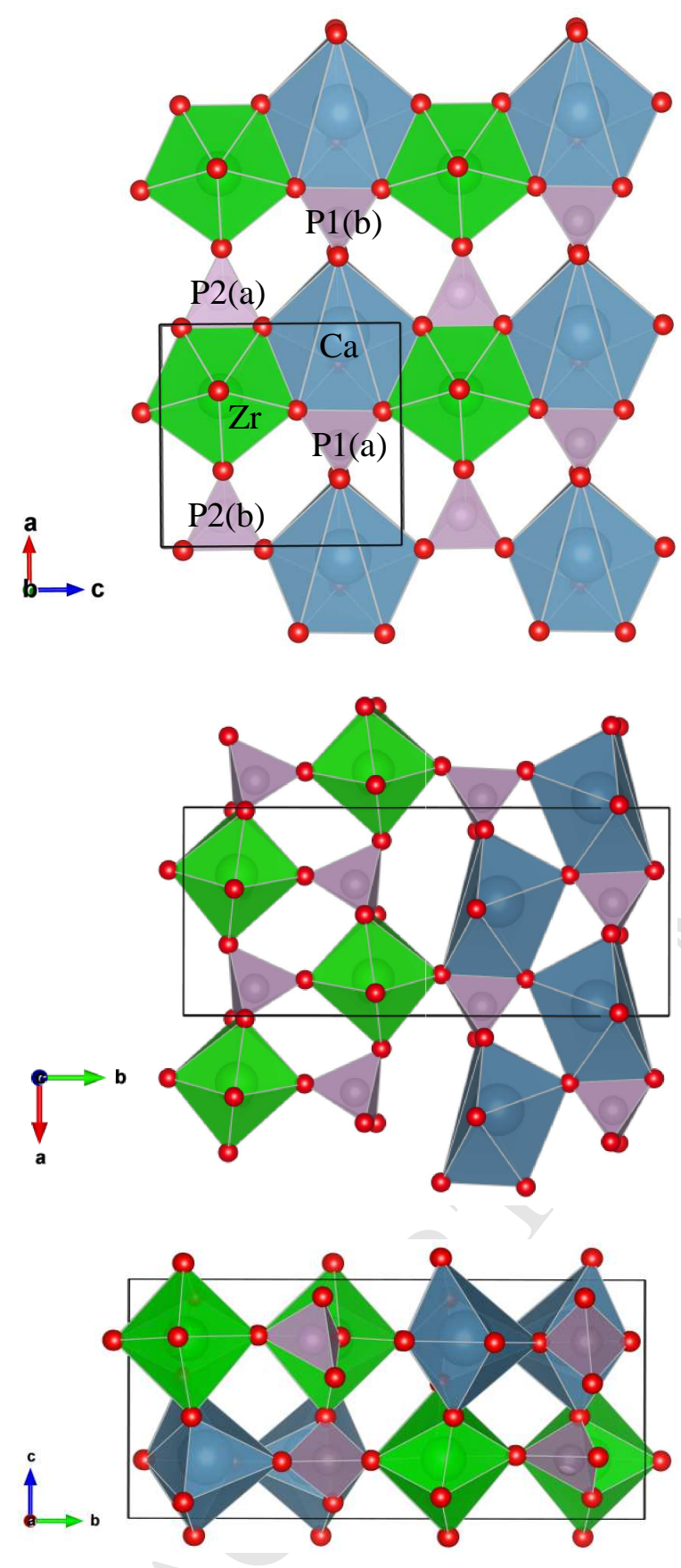

Fig. 1. Views of the structure of $\alpha-\mathrm{CaZr}\left(\mathrm{PO}_{4}\right)_{2}$ 

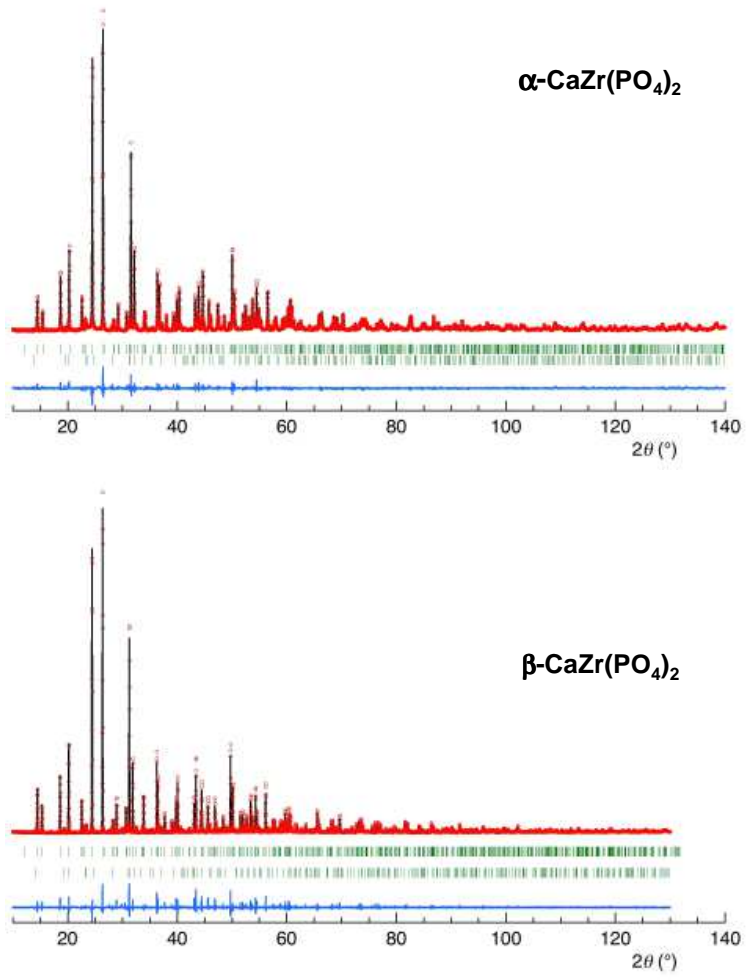

Fig. 2. Rietveld plots for $\alpha-\mathrm{CaZr}\left(\mathrm{PO}_{4}\right)_{2}$ and $\beta-\mathrm{CaZr}\left(\mathrm{PO}_{4}\right)_{2}: y_{o b s}$ (dots), $y_{\text {calc }}$ (solid, upper), $y_{\text {obs }}{ }^{-}$ $y_{\text {calc }}$ (solid, lower), Bragg positions (bars) 

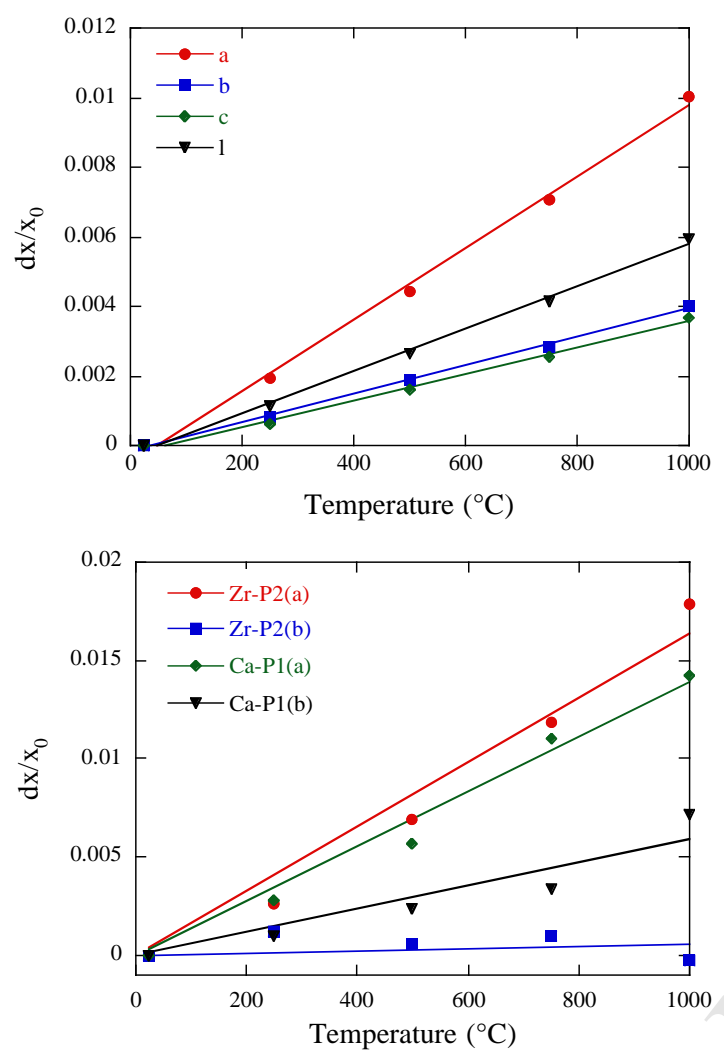

Fig. 3. Thermal evolution of the cell parameters (a) and Ca-P and Zr-P distances (b, see Fig. 1. for atoms nomenclature) 


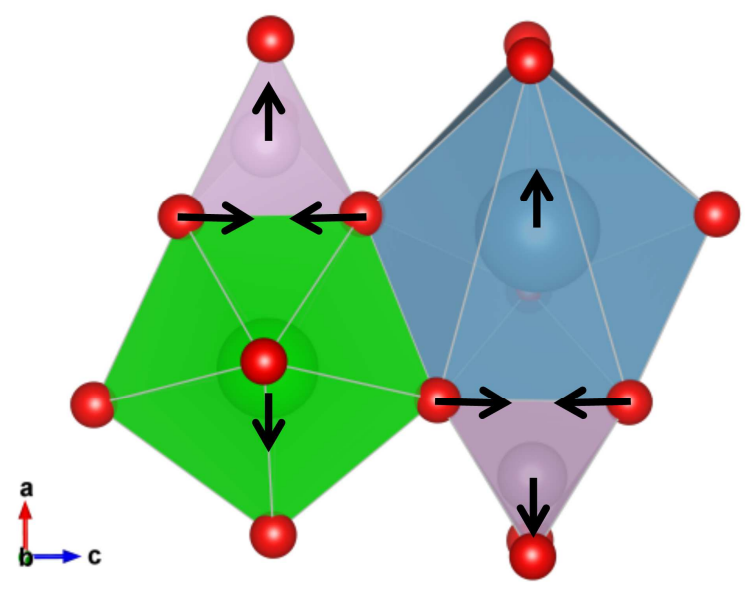

Fig. 4. Coulombic repulsions between cations lead to high thermal expansion along $a$ and low thermal expansion along $c$ 


\section{Highlights:}

Room temperature structure $\mathrm{CaZr}\left(\mathrm{PO}_{4}\right)_{2}$ was revised

A high temperature form of $\mathrm{CaZr}\left(\mathrm{PO}_{4}\right)_{2}$ was described for the first time

Thermal expansion of $\mathrm{CaZr}\left(\mathrm{PO}_{4}\right)_{2}$ was studied on the basis of the evolution of the crystal parameters evolution during heating 


\section{checkCIF/PLATON report}

You have not supplied any structure factors. As a result the full set of tests cannot be run.

THIS REPORT IS FOR GUIDANCE ONLY. IF USED AS PART OF A REVIEW PROCEDURE FOR PUBLICATION, IT SHOULD NOT REPLACE THE EXPERTISE OF AN EXPERIENCED CRYSTALLOGRAPHIC REFEREE.

No syntax errors found. CIF dictionary Interpreting this report

\section{Datablock: I}

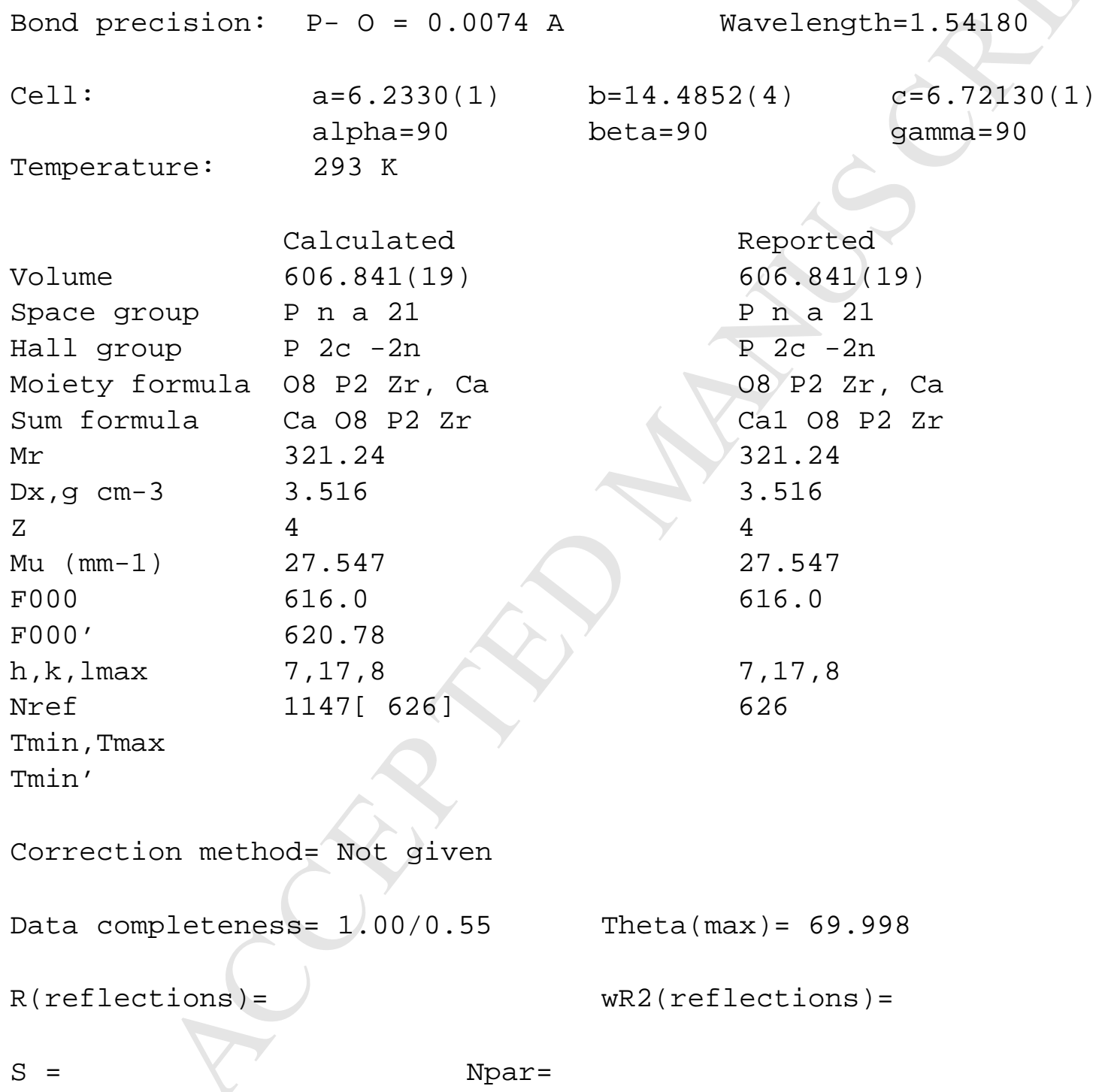


Alert level $B$

PLAT111_ALERT_2_B ADDSYM Detects (Pseudo) Centre of Symmetry .....

Alert level $\mathrm{C}$

PLAT163_ALERT_4_C Missing or Zero su (esd) on z-coordinate for... ZR

PLAT213_ALERT_2_C Atom Ca has ADP max/min Ratio..... 3.9 prolat

Alert level $\mathbf{G}$

PLAT004_ALERT_5_G Polymeric Structure Found with Dimension .......

PLAT112_ALERT_2_G ADDSYM Detects Additional (Pseudo) Symm. Elem...

PLAT113_ALERT_2_G ADDSYM Suggests Possible Pseudo/New Space group.

PLAT143_ALERT_4_G su on $\mathrm{c}$ - Axis Small or Missing ............

PLAT794_ALERT_5_G Tentative Bond Valency for Zr Zr (IV) $\ldots .$.

PLAT860_ALERT_3_G Number of Least-Squares Restraints ..........

PLAT982_ALERT_1_G The Ca-f'= 0.341 Deviates from the IT-value

PLAT982_ALERT_1_G The $0-f^{\prime}=0.047$ Deviates from the IT-value

PLAT982_ALERT_1_G The $P-f^{\prime}=0.283$ Deviates from the IT-value

PLAT982_ALERT_1_G The Zr-f'= -0.314 Deviates from the IT-value

3 Info

m Check

Pnma Check

0.00001 Ang.

4.33 Note

8 Note

0.364 Check

0.049 Check

0.296 Check

-0.186 Check

0 ALERT level $\mathbf{A}=$ Most likely a serious problem - resolve or explain

1 ALERT level $\mathbf{B}=\mathrm{A}$ potentially serious problem, consider carefully

2 ALERT level $\mathbf{C}=$ Check. Ensure it is not caused by an omission or oversight

10 ALERT level $\mathbf{G}=$ General information/check it is not something unexpected

4 ALERT type 1 CIF construction/syntax error, inconsistent or missing data

4 ALERT type 2 Indicator that the structure model may be wrong or deficient

1 ALERT type 3 Indicator that the structure quality may be low

2 ALERT type 4 Improvement, methodology, query or suggestion

2 ALERT type 5 Informative message, check 
It is advisable to attempt to resolve as many as possible of the alerts in all categories. Often the minor alerts point to easily fixed oversights, errors and omissions in your CIF or refinement strategy, so attention to these fine details can be worthwhile. In order to resolve some of the more serious problems it may be necessary to carry out additional measurements or structure refinements. However, the purpose of your study may justify the reported deviations and the more serious of these should normally be commented upon in the discussion or experimental section of a paper or in the "special_details" fields of the CIF. checkCIF was carefully designed to identify outliers and unusual parameters, but every test has its limitations and alerts that are not important in a particular case may appear. Conversely, the absence of alerts does not guarantee there are no aspects of the results needing attention. It is up to the individual to critically assess their own results and, if necessary, seek expert advice.

\section{Publication of your CIF in IUCr journals}

A basic structural check has been run on your CIF. These basic checks will be run on all CIFs submitted for publication in IUCr journals (Acta Crystallographica, Journal of Applied Crystallography, Journal of Synchrotron Radiation); however, if you intend to submit to Acta Crystallographica Section $C$ or $E$, you should make sure that full publication checks are run on the final version of your CIF prior to submission.

\section{Publication of your CIF in other journals}

Please refer to the Notes for Authors of the relevant journal for any special instructions relating to CIF submission.

\section{PLATON version of 20/08/2014; check.def file version of 18/08/2014}


ACCEPTED MANUSCRIPT

Datablock I - ellipsoid plot

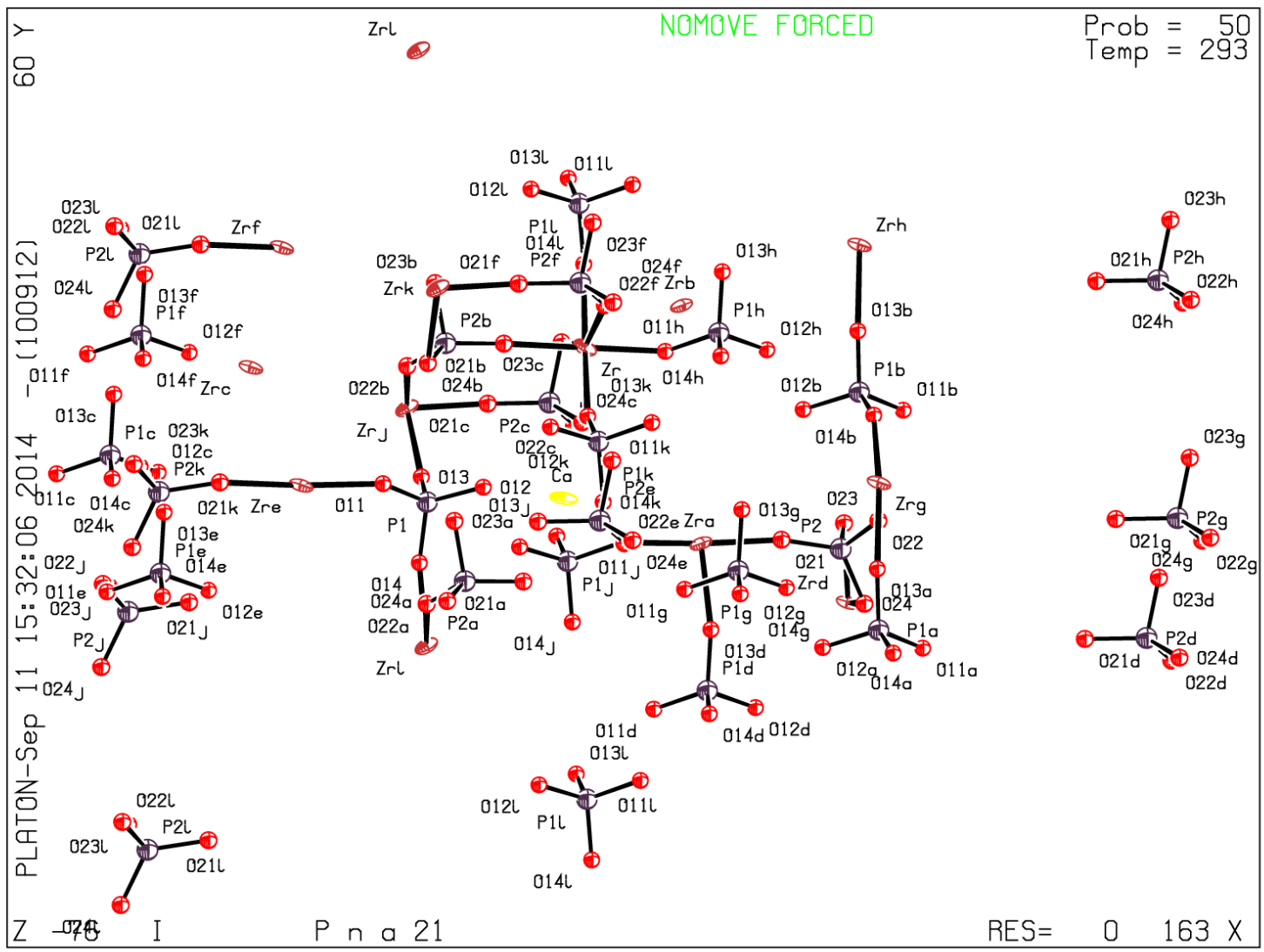




\section{checkCIF/PLATON report}

You have not supplied any structure factors. As a result the full set of tests cannot be run.

THIS REPORT IS FOR GUIDANCE ONLY. IF USED AS PART OF A REVIEW PROCEDURE FOR PUBLICATION, IT SHOULD NOT REPLACE THE EXPERTISE OF AN EXPERIENCED CRYSTALLOGRAPHIC REFEREE.

No syntax errors found. CIF dictionary Interpreting this report

\section{Datablock: I}

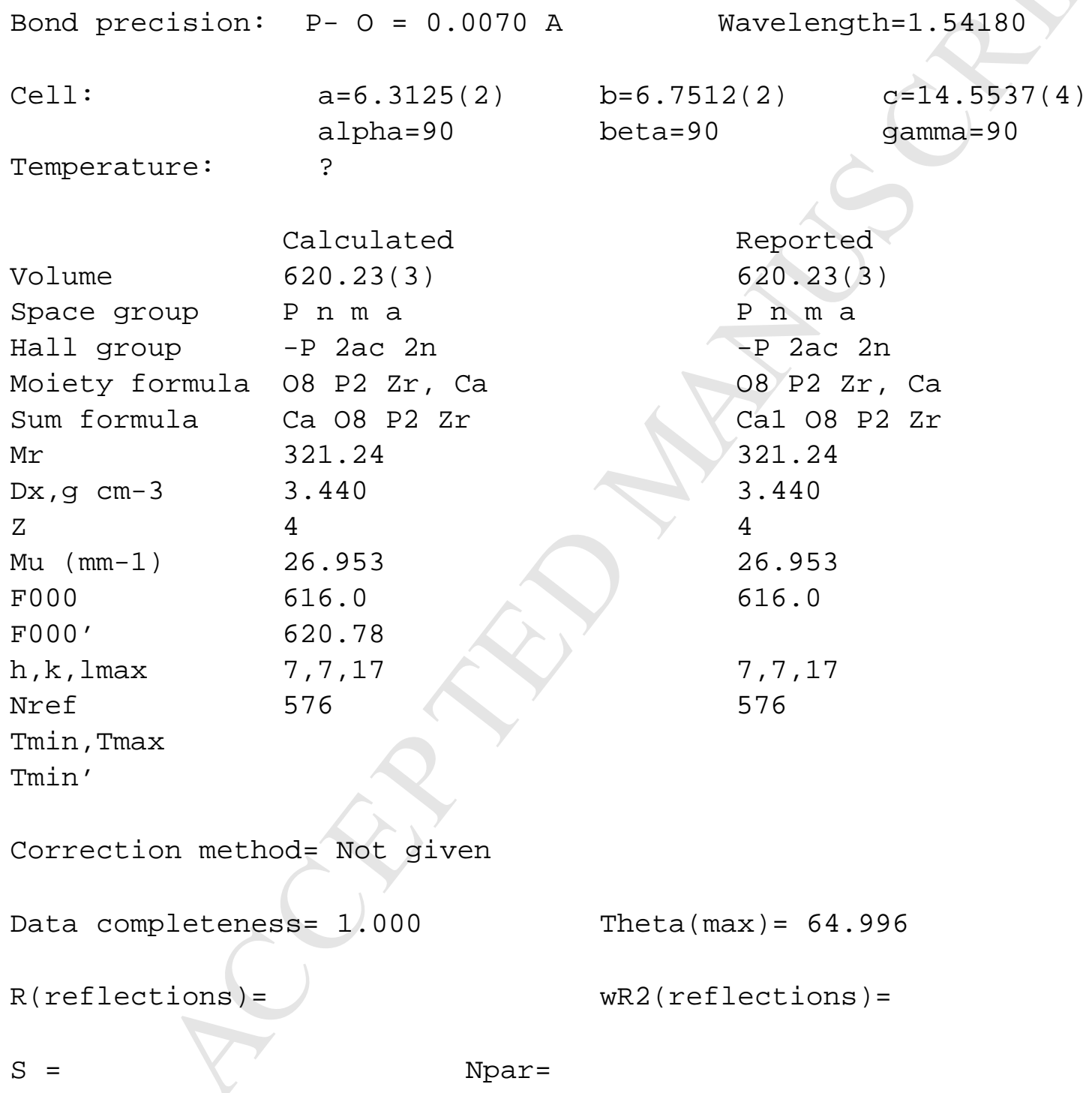


Alert level $\mathbf{G}$

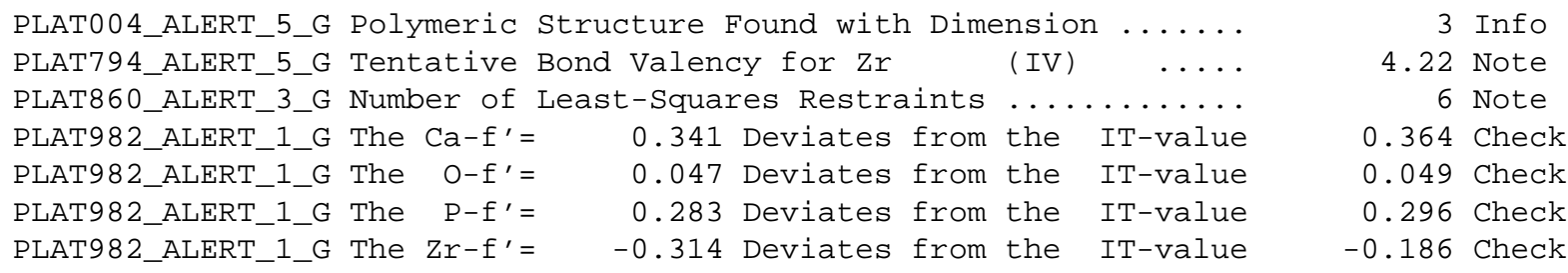

0 ALERT level $\mathbf{A}=$ Most likely a serious problem - resolve or explain

0 ALERT level $\mathbf{B}=\mathrm{A}$ potentially serious problem, consider carefully

0 ALERT level $\mathbf{C}=$ Check. Ensure it is not caused by an omission or oversight

7 ALERT level $\mathbf{G}=$ General information/check it is not something unexpected

4 ALERT type 1 CIF construction/syntax error, inconsistent or missing data

0 ALERT type 2 Indicator that the structure model may be wrong or deficient

1 ALERT type 3 Indicator that the structure quality may be low

0 ALERT type 4 Improvement, methodology, query or suggestion

2 ALERT type 5 Informative message, check

It is advisable to attempt to resolve as many as possible of the alerts in all categories. Often the minor alerts point to easily fixed oversights, errors and omissions in your CIF or refinement strategy, so attention to these fine details can be worthwhile. In order to resolve some of the more serious problems it may be necessary to carry out additional measurements or structure refinements. However, the purpose of your study may justify the reported deviations and the more serious of these should normally be commented upon in the discussion or experimental section of a paper or in the "special_details" fields of the CIF. checkCIF was carefully designed to identify outliers and unusual parameters, but every test has its limitations and alerts that are not important in a particular case may appear. Conversely, the absence of alerts does not guarantee there are no aspects of the results needing attention. It is up to the individual to critically assess their own results and, if necessary, seek expert advice.

\section{Publication of your CIF in IUCr journals}

A basic structural check has been run on your CIF. These basic checks will be run on all CIFs submitted for publication in IUCr journals (Acta Crystallographica, Journal of Applied

Crystallography, Journal of Synchrotron Radiation); however, if you intend to submit to Acta Crystallographica Section $C$ or $E$, you should make sure that full publication checks are run on the final version of your CIF prior to submission.

\section{Publication of your CIF in other journals}

Please refer to the Notes for Authors of the relevant journal for any special instructions relating to CIF submission.

\section{PLATON version of 20/08/2014; check.def file version of 18/08/2014}




\section{ACCEPTED MANUSCRIPT}

Datablock I - ellipsoid plot

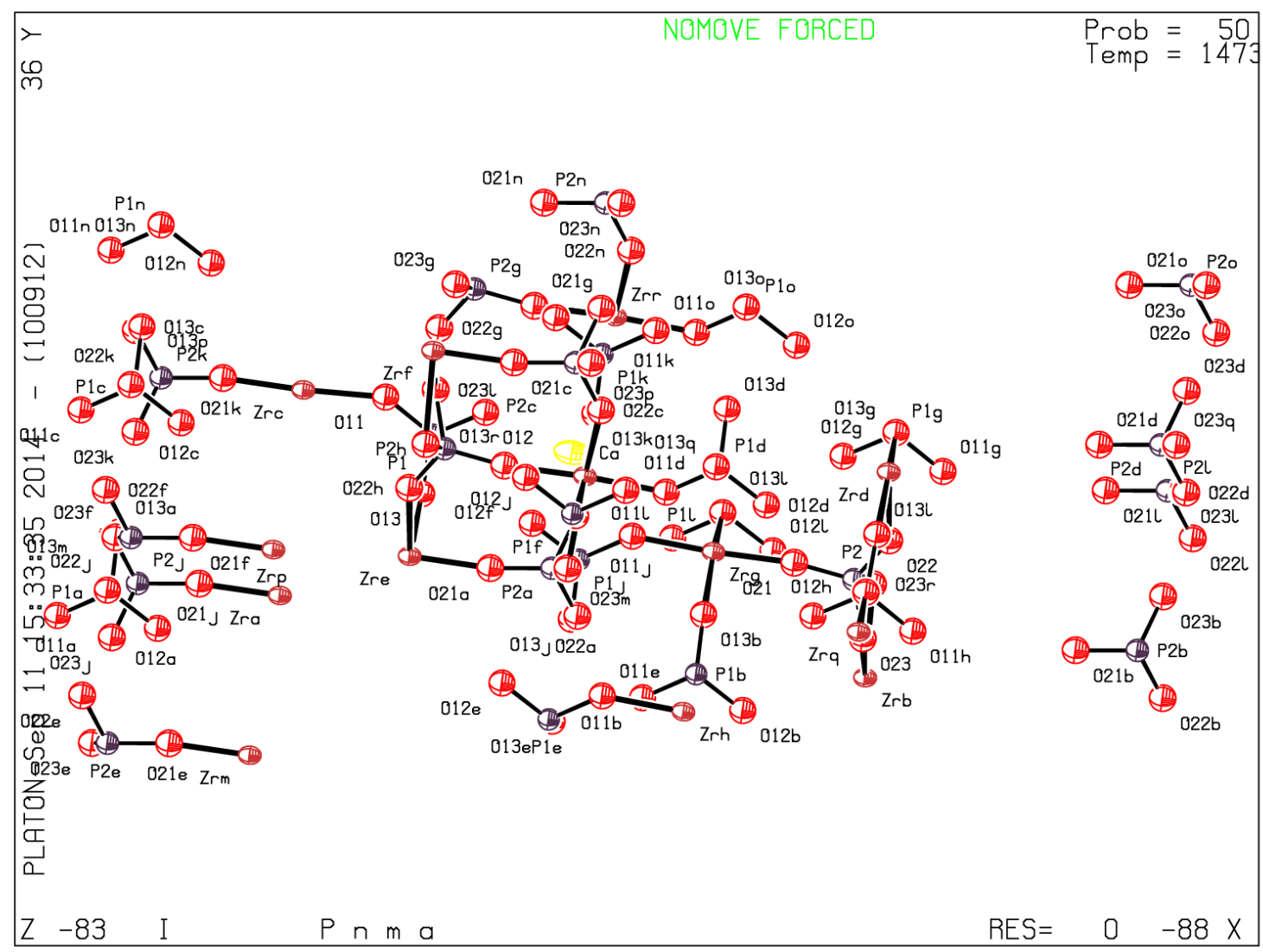


The following list summarizes all the diffraction peaks of $\mathrm{CaZr}\left(\mathrm{PO}_{4}\right)_{2}$ up to $80^{\circ}$, measured by Fullprof assuming Fukuda's $P 2_{1} 2_{1} 2_{1}$ space group. Maximum intensity is 26204 counts (002). Reflections in red, all below detection threshold, account for $0 k l, k+l=2 n+1$ or $h 0 l, h=2 n+1$ extinctions. Strongly overlapped peaks, yellow highlighted, should not be taken into account.

\begin{tabular}{|c|c|c|c|c|c|c|c|c|}
\hline $\mathrm{h}$ & k & 1 & Mult & Freal & Fimag & $2 T$ & Intensity & Cod \\
\hline 0 & 2 & 0 & 2 & 0.0000 & 0.0000 & 12.2092 & 0.0000 & 0 \\
\hline 0 & 1 & 1 & 4 & 0.0000 & 0.0000 & 14.5146 & 2997.7495 & 0 \\
\hline 1 & 1 & 0 & 4 & 0.0000 & 0.0000 & 15.4620 & 1794.1384 & 0 \\
\hline 0 & 2 & 1 & 4 & 0.0000 & 0.0000 & 17.9882 & 0.0000 & 0 \\
\hline 1 & 2 & 0 & 4 & 0.0000 & 0.0000 & 18.7653 & 5256.6631 & 0 \\
\hline 1 & 0 & 1 & 4 & 0.0000 & 0.0000 & 19.4039 & 0.0771 & 0 \\
\hline 1 & 1 & 1 & 8 & 0.0000 & 0.0000 & 20.3566 & 7532.6211 & 0 \\
\hline 0 & 3 & 1 & 4 & 0.0000 & 0.0000 & 22.6540 & 3273.5964 & 0 \\
\hline 1 & 2 & 1 & 8 & 0.0000 & 0.0000 & 22.9886 & 33.3553 & 0 \\
\hline 1 & 3 & 0 & 4 & 0.0000 & 0.0000 & 23.2818 & 665.7825 & 0 \\
\hline 0 & 4 & 0 & 2 & 0.0000 & 0.0000 & 24.5598 & 24134.3359 & 0 \\
\hline 0 & 0 & 2 & 2 & 0.0000 & 0.0000 & 26.4976 & 26204.9336 & 0 \\
\hline 1 & 3 & 1 & 8 & 0.0000 & 0.0000 & 26.8350 & 0.9629 & 0 \\
\hline 0 & 1 & 2 & 4 & 0.0000 & 0.0000 & 27.2148 & 31.4433 & 0 \\
\hline 0 & 4 & 1 & 4 & 0.0000 & 0.0000 & 27.9611 & 0.5058 & 0 \\
\hline 1 & 4 & 0 & 4 & 0.0000 & 0.0000 & 28.4792 & 1015.1817 & 0 \\
\hline 2 & 0 & 0 & 2 & 0.0000 & 0.0000 & 28.6161 & 0.3218 & 0 \\
\hline 0 & 2 & 2 & 4 & 0.0000 & 0.0000 & 29.2689 & 693.7385 & 0 \\
\hline 2 & 1 & 0 & 4 & 0.0000 & 0.0000 & 29.2854 & 1676.3821 & 0 \\
\hline 1 & 0 & 2 & 4 & 0.0000 & 0.0000 & 30.1840 & 0.0000 & 0 \\
\hline 1 & 1 & 2 & 8 & 0.0000 & 0.0000 & 30.8223 & 1527.0349 & 0 \\
\hline 2 & 2 & 0 & 4 & 0.0000 & 0.0000 & 31.2148 & 112.6263 & 0 \\
\hline 1 & 4 & 1 & 8 & 0.0000 & 0.0000 & 31.4903 & 140.5853 & 0 \\
\hline
\end{tabular}




\section{ACCEPTED MANUSCRIPT}

\begin{tabular}{|c|c|c|c|c|c|c|c|}
\hline 2 & 0 & 1 & 4 & 0.0000 & 0.0000 & 31.6153 & 16395.0742 \\
\hline 2 & 1 & 1 & 8 & 0.0000 & 0.0000 & 32.2281 & 7420.8955 \\
\hline 0 & 3 & 2 & 4 & 0.0000 & 0.0000 & 32.4284 & 25.3111 \\
\hline 1 & 2 & 2 & 8 & 0.0000 & 0.0000 & 32.6696 & 497.6013 \\
\hline 0 & 5 & 1 & 4 & 0.0000 & 0.0000 & 33.6564 & 0.0000 \\
\hline 2 & 2 & 1 & 8 & 0.0000 & 0.0000 & 34.0071 & 608.8705 \\
\hline 1 & 5 & 0 & 4 & 0.0000 & 0.0000 & 34.0960 & 1613.0172 \\
\hline 2 & 3 & 0 & 4 & 0.0000 & 0.0000 & 34.2125 & 1666.0769 \\
\hline 1 & 3 & 2 & 8 & 0.0000 & 0.0000 & 35.5583 & 311.9702 \\
\hline 0 & 4 & 2 & 4 & 0.0000 & 0.0000 & 36.4398 & 6432.3965 \\
\hline 1 & 5 & 1 & 8 & 0.0000 & 0.0000 & 36.6940 & 1251.1421 \\
\hline 2 & 3 & 1 & 8 & 0.0000 & 0.0000 & 36.8034 & 4458.2886 \\
\hline 0 & 6 & 0 & 2 & 0.0000 & 0.0000 & 37.2087 & 630.6879 \\
\hline 2 & 4 & 0 & 4 & 0.0000 & 0.0000 & 38.0590 & 1598.5714 \\
\hline 1 & 4 & 2 & 8 & 0.0000 & 0.0000 & 39.2907 & 425.3597 \\
\hline 2 & 0 & 2 & 4 & 0.0000 & 0.0000 & 39.3939 & 1463.3533 \\
\hline 0 & 6 & 1 & 4 & 0.0000 & 0.0000 & 39.6303 & 2.4266 \\
\hline 2 & 1 & 2 & 8 & 0.0000 & 0.0000 & 39.9016 & 287.0677 \\
\hline 1 & 6 & 0 & 4 & 0.0000 & 0.0000 & 40.0129 & 3504.2375 \\
\hline 2 & 4 & 1 & 8 & 0.0000 & 0.0000 & 40.4374 & 4483.2822 \\
\hline 0 & 1 & 3 & 4 & 0.0000 & 0.0000 & 40.7127 & 343.4568 \\
\hline 0 & 5 & 2 & 4 & 0.0000 & 0.0000 & 41.0976 & 0.0063 \\
\hline 2 & 2 & 2 & 8 & 0.0000 & 0.0000 & 41.3937 & 178.6885 \\
\hline 0 & 2 & 3 & 4 & 0.0000 & 0.0000 & 42.1811 & 0.0000 \\
\hline 1 & 6 & 1 & 8 & 0.0000 & 0.0000 & 42.2994 & 65.0679 \\
\hline 2 & 5 & 0 & 4 & 0.0000 & 0.0000 & 42.5671 & 182.8900 \\
\hline 1 & 0 & 3 & 4 & 0.0000 & 0.0000 & 42.8526 & 0.0865 \\
\hline
\end{tabular}




\section{ACCEPTED MANUSCRIPT}

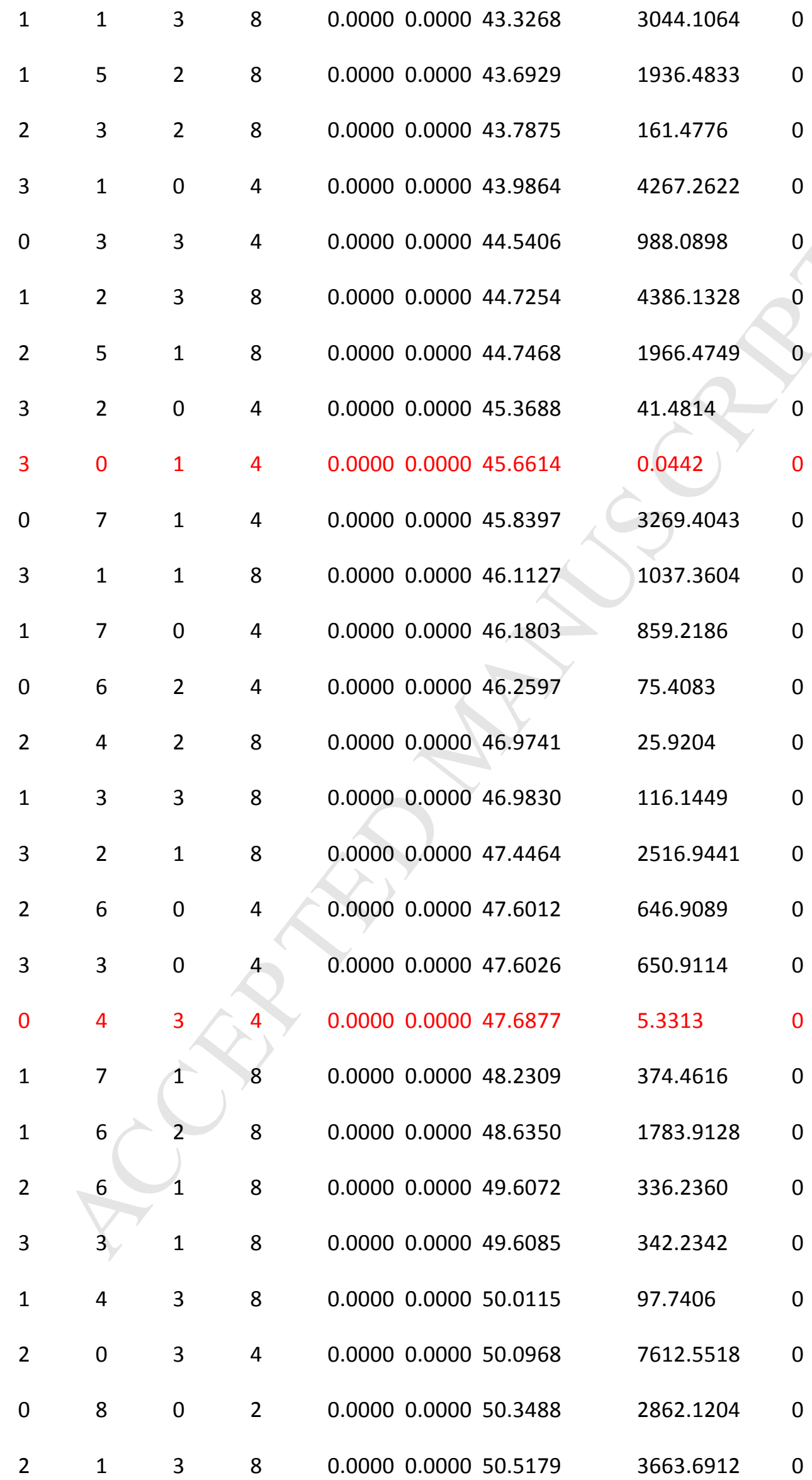




\section{ACCEPTED MANUSCRIPT}

\begin{tabular}{|c|c|c|c|c|c|c|c|}
\hline 3 & 4 & 0 & 4 & 0.0000 & 0.0000 & 50.6032 & 82.4974 \\
\hline 2 & 5 & 2 & 8 & 0.0000 & 0.0000 & 50.8436 & 37.3449 \\
\hline 0 & 5 & 3 & 4 & 0.0000 & 0.0000 & 51.5171 & 61.5790 \\
\hline 3 & 0 & 2 & 4 & 0.0000 & 0.0000 & 51.6757 & 1.3276 \\
\hline 2 & 2 & 3 & 8 & 0.0000 & 0.0000 & 51.7660 & 87.8422 \\
\hline 0 & 7 & 2 & 4 & 0.0000 & 0.0000 & 51.8383 & 16.0640 \\
\hline 3 & 1 & 2 & 8 & 0.0000 & 0.0000 & 52.0875 & 1467.9346 \\
\hline 0 & 8 & 1 & 4 & 0.0000 & 0.0000 & 52.2766 & 16.3894 \\
\hline 3 & 4 & 1 & 8 & 0.0000 & 0.0000 & 52.5243 & 2072.3459 \\
\hline 1 & 8 & 0 & 4 & 0.0000 & 0.0000 & 52.5857 & 818.1835 \\
\hline 2 & 7 & 0 & 4 & 0.0000 & 0.0000 & 53.0744 & 1383.9629 \\
\hline 3 & 2 & 2 & 8 & 0.0000 & 0.0000 & 53.3094 & 386.5337 \\
\hline 1 & 5 & 3 & 8 & 0.0000 & 0.0000 & 53.7192 & 1152.9529 \\
\hline 2 & 3 & 3 & 8 & 0.0000 & 0.0000 & 53.8003 & 2949.6833 \\
\hline 1 & 7 & 2 & 8 & 0.0000 & 0.0000 & 54.0312 & 463.6395 \\
\hline 3 & 5 & 0 & 4 & 0.0000 & 0.0000 & 54.2820 & 1270.4956 \\
\hline 1 & 8 & 1 & 8 & 0.0000 & 0.0000 & 54.4571 & 0.0563 \\
\hline 0 & 0 & 4 & 2 & 0.0000 & 0.0000 & 54.5627 & 4191.3540 \\
\hline 2 & 7 & 1 & 8 & 0.0000 & 0.0000 & 54.9342 & 1801.9020 \\
\hline 0 & 1 & 4 & 4 & 0.0000 & 0.0000 & 54.9594 & 395.2951 \\
\hline 2 & 6 & 2 & 8 & 0.0000 & 0.0000 & 55.3028 & 414.8722 \\
\hline 3 & & 2 & 8 & 0.0000 & 0.0000 & 55.3041 & 421.5350 \\
\hline 0 & 6 & 3 & 4 & 0.0000 & 0.0000 & 55.9385 & 0.0000 \\
\hline 3 & 5 & 1 & 8 & 0.0000 & 0.0000 & 56.1145 & 7.5141 \\
\hline 0 & 2 & 4 & 4 & 0.0000 & 0.0000 & 56.1381 & 2.8176 \\
\hline 2 & 4 & 3 & 8 & 0.0000 & 0.0000 & 56.5630 & 4396.1016 \\
\hline 1 & 0 & 4 & 4 & 0.0000 & 0.0000 & 56.6828 & 173.4236 \\
\hline
\end{tabular}




\section{ACCEPTED MANUSCRIPT}

\begin{tabular}{|c|c|c|c|c|c|c|c|}
\hline 1 & 1 & 4 & 8 & 0.0000 & 0.0000 & 57.0697 & 253.7804 \\
\hline 0 & 8 & 2 & 4 & 0.0000 & 0.0000 & 57.7872 & 1060.2554 \\
\hline 3 & 4 & 2 & 8 & 0.0000 & 0.0000 & 58.0189 & 755.2390 \\
\hline 1 & 6 & 3 & 8 & 0.0000 & 0.0000 & 58.0253 & 546.9765 \\
\hline 0 & 3 & 4 & 4 & 0.0000 & 0.0000 & 58.0674 & 99.0517 \\
\hline 1 & 2 & 4 & 8 & 0.0000 & 0.0000 & 58.2202 & 346.3297 \\
\hline 3 & 6 & 0 & 4 & 0.0000 & 0.0000 & 58.5606 & 0.0000 \\
\hline 2 & 8 & 0 & 4 & 0.0000 & 0.0000 & 58.9383 & 28.3580 \\
\hline 0 & 9 & 1 & 4 & 0.0000 & 0.0000 & 58.9541 & 39.6393 \\
\hline 1 & 9 & 0 & 4 & 0.0000 & 0.0000 & 59.2397 & 475.3760 \\
\hline 4 & 0 & 0 & 2 & 0.0000 & 0.0000 & 59.2433 & 548.9984 \\
\hline 4 & 1 & 0 & 4 & 0.0000 & 0.0000 & 59.6196 & 1106.3279 \\
\hline 1 & 8 & 2 & 8 & 0.0000 & 0.0000 & 59.8327 & 554.9004 \\
\hline 2 & 5 & 3 & 8 & 0.0000 & 0.0000 & 59.9914 & 1265.1919 \\
\hline 1 & 3 & 4 & 8 & 0.0000 & 0.0000 & 60.1069 & 106.1573 \\
\hline 2 & 7 & 2 & 8 & 0.0000 & 0.0000 & 60.2820 & 1011.7947 \\
\hline 3 & 6 & 1 & 8 & 0.0000 & 0.0000 & 60.3081 & 1732.4614 \\
\hline 2 & 8 & 1 & 8 & 0.0000 & 0.0000 & 60.6792 & 1939.9963 \\
\hline 0 & 4 & 4 & 4 & 0.0000 & 0.0000 & 60.7028 & 1070.0323 \\
\hline 3 & 0 & 3 & 4 & 0.0000 & 0.0000 & 60.7381 & 227.4752 \\
\hline 4 & 2 & 0 & 4 & 0.0000 & 0.0000 & 60.7399 & 231.7396 \\
\hline 0 & 7 & 3 & 4 & 0.0000 & 0.0000 & 60.8844 & 1333.6071 \\
\hline 1 & 9 & 1 & 8 & 0.0000 & 0.0000 & 60.9753 & 1024.7820 \\
\hline 4 & 0 & 1 & 4 & 0.0000 & 0.0000 & 60.9789 & 991.2356 \\
\hline 3 & 1 & 3 & 8 & 0.0000 & 0.0000 & 61.1088 & 186.9957 \\
\hline 4 & 1 & 1 & 8 & 0.0000 & 0.0000 & 61.3487 & 657.1586 \\
\hline 3 & 5 & 2 & 8 & 0.0000 & 0.0000 & 61.3963 & 339.9083 \\
\hline
\end{tabular}




\section{ACCEPTED MANUSCRIPT}

\begin{tabular}{|c|c|c|c|c|c|c|c|}
\hline 3 & 2 & 3 & 8 & 0.0000 & 0.0000 & 62.2131 & 498.6354 \\
\hline 4 & 2 & 1 & 8 & 0.0000 & 0.0000 & 62.4506 & 22.3768 \\
\hline 4 & 3 & 0 & 4 & 0.0000 & 0.0000 & 62.5804 & 853.1497 \\
\hline 1 & 4 & 4 & 8 & 0.0000 & 0.0000 & 62.6902 & 121.0082 \\
\hline 2 & 0 & 4 & 4 & 0.0000 & 0.0000 & 62.7638 & 199.6674 \\
\hline 1 & 7 & 3 & 8 & 0.0000 & 0.0000 & 62.8684 & 68.6504 \\
\hline 2 & 1 & 4 & 8 & 0.0000 & 0.0000 & 63.1276 & 199.2425 \\
\hline 3 & 7 & 0 & 4 & 0.0000 & 0.0000 & 63.3789 & 0.0000 \\
\hline 0 & 5 & 4 & 4 & 0.0000 & 0.0000 & 63.9950 & 63.7381 \\
\hline & & & & & & & 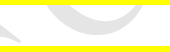 \\
\hline 2 & 6 & 3 & 8 & 0.0000 & 0.0000 & 64.0281 & 66.8532 \\
\hline 3 & 3 & 3 & 8 & 0.0000 & 0.0000 & 64.0293 & 53.3899 \\
\hline 0 & 9 & 2 & 4 & 0.0000 & 0.0000 & 64.0913 & 26.7765 \\
\hline 2 & 2 & 4 & 8 & 0.0000 & 0.0000 & 64.2121 & 44.4616 \\
\hline 0 & 10 & 0 & 2 & 0.0000 & 0.0000 & 64.2433 & 189.9777 \\
\hline 4 & 3 & 1 & 8 & 0.0000 & 0.0000 & 64.2630 & 325.2186 \\
\hline 3 & 7 & 1 & 8 & 0.0000 & 0.0000 & 65.0500 & 276.8649 \\
\hline 4 & 4 & 0 & 4 & 0.0000 & 0.0000 & 65.1072 & 57.4412 \\
\hline 2 & 9 & 0 & 4 & 0.0000 & 0.0000 & 65.1759 & 39.5526 \\
\hline 3 & 6 & 2 & 8 & 0.0000 & 0.0000 & 65.3830 & 467.1862 \\
\hline 2 & 8 & 2 & 8 & 0.0000 & 0.0000 & 65.7378 & 63.7310 \\
\hline 0 & 10 & 1 & 4 & 0.0000 & 0.0000 & 65.9026 & 284.3600 \\
\hline 1 & & 4 & 8 & 0.0000 & 0.0000 & 65.9263 & 366.6651 \\
\hline 2 & 3 & 4 & 8 & 0.0000 & 0.0000 & 65.9980 & 415.4911 \\
\hline 1 & 9 & 2 & 8 & 0.0000 & 0.0000 & 66.0211 & 732.0118 \\
\hline 4 & 0 & 2 & 4 & 0.0000 & 0.0000 & 66.0245 & 581.8456 \\
\hline 1 & 10 & 0 & 4 & 0.0000 & 0.0000 & 66.1707 & 304.7988 \\
\hline 0 & 8 & 3 & 4 & 0.0000 & 0.0000 & 66.3120 & 60.9734 \\
\hline
\end{tabular}




\section{ACCEPTED MANUSCRIPT}

\begin{tabular}{|c|c|c|c|c|c|c|c|}
\hline 4 & 1 & 2 & 8 & 0.0000 & 0.0000 & 66.3786 & 1677.4912 \\
\hline 3 & 4 & 3 & 8 & 0.0000 & 0.0000 & 66.5261 & 897.4345 \\
\hline 4 & 4 & 1 & 8 & 0.0000 & 0.0000 & 66.7552 & 27.3313 \\
\hline 2 & 9 & 1 & 8 & 0.0000 & 0.0000 & 66.8230 & 73.7172 \\
\hline 4 & 2 & 2 & 8 & 0.0000 & 0.0000 & 67.4352 & 39.1420 \\
\hline 1 & 10 & 1 & 8 & 0.0000 & 0.0000 & 67.8056 & 54.7734 \\
\hline 0 & 6 & 4 & 4 & 0.0000 & 0.0000 & 67.8984 & 33.7244 \\
\hline 1 & 8 & 3 & 8 & 0.0000 & 0.0000 & 68.2092 & 128.9127 \\
\hline 4 & 5 & 0 & 4 & 0.0000 & 0.0000 & 68.2825 & 474.0534 \\
\hline 2 & 4 & 4 & 8 & 0.0000 & 0.0000 & 68.4577 & 63.3874 \\
\hline 2 & 7 & 3 & 8 & 0.0000 & 0.0000 & 68.6280 & 1628.9163 \\
\hline 3 & 8 & 0 & 4 & 0.0000 & 0.0000 & 68.6988 & 213.5349 \\
\hline 4 & 3 & 2 & 8 & 0.0000 & 0.0000 & 69.1786 & 1449.4451 \\
\hline 3 & 5 & 3 & 8 & 0.0000 & 0.0000 & 69.6692 & 80.0715 \\
\hline 1 & 6 & 4 & 8 & 0.0000 & 0.0000 & 69.7748 & 570.3260 \\
\hline 4 & 5 & 1 & 8 & 0.0000 & 0.0000 & 69.8933 & 203.7105 \\
\hline 3 & 7 & 2 & 8 & 0.0000 & 0.0000 & 69.9377 & 156.1405 \\
\hline 0 & 1 & 5 & 4 & 0.0000 & 0.0000 & 70.2571 & 107.3998 \\
\hline 3 & 8 & 1 & 8 & 0.0000 & 0.0000 & 70.3052 & 2200.3604 \\
\hline 0 & 10 & 2 & 4 & 0.0000 & 0.0000 & 70.7614 & 11.0434 \\
\hline 0 & 2 & 5 & 4 & 0.0000 & 0.0000 & 71.2864 & 7.5031 \\
\hline 2 & 5 & 4 & 8 & 0.0000 & 0.0000 & 71.5609 & 60.2032 \\
\hline 4 & 4 & 2 & 8 & 0.0000 & 0.0000 & 71.5864 & 63.8000 \\
\hline 2 & 9 & 2 & 8 & 0.0000 & 0.0000 & 71.6520 & 0.0016 \\
\hline 1 & 0 & 5 & 4 & 0.0000 & 0.0000 & 71.7649 & 5.2505 \\
\hline 2 & 10 & 0 & 4 & 0.0000 & 0.0000 & 71.7961 & 51.9457 \\
\hline 4 & 6 & 0 & 4 & 0.0000 & 0.0000 & 72.0714 & 0.0003 \\
\hline
\end{tabular}




\section{ACCEPTED MANUSCRIPT}

\begin{tabular}{|c|c|c|c|c|c|c|c|}
\hline 1 & 1 & 5 & 8 & 0.0000 & 0.0000 & 72.1057 & 173.8652 \\
\hline 0 & 9 & 3 & 4 & 0.0000 & 0.0000 & 72.2039 & 0.0000 \\
\hline 3 & 0 & 4 & 4 & 0.0000 & 0.0000 & 72.2436 & 0.0000 \\
\hline 0 & 7 & 4 & 4 & 0.0000 & 0.0000 & 72.3777 & 0.0000 \\
\hline 3 & 1 & 4 & 8 & 0.0000 & 0.0000 & 72.5835 & 281.5065 \\
\hline 1 & 10 & 2 & 8 & 0.0000 & 0.0000 & 72.6045 & 0.0015 \\
\hline 0 & 3 & 5 & 4 & 0.0000 & 0.0000 & 72.9884 & 0.0000 \\
\hline 1 & 2 & 5 & 8 & 0.0000 & 0.0000 & 73.1241 & 0.0000 \\
\hline 0 & 11 & 1 & 4 & 0.0000 & 0.0000 & 73.1693 & 0.0000 \\
\hline 2 & 10 & 1 & 8 & 0.0000 & 0.0000 & 73.3732 & 0.0000 \\
\hline 1 & 11 & 0 & 4 & 0.0000 & 0.0000 & 73.4251 & 212.2202 \\
\hline 3 & 6 & 3 & 8 & 0.0000 & 0.0000 & 73.4268 & 169.8904 \\
\hline 3 & 2 & 4 & 8 & 0.0000 & 0.0000 & 73.5994 & 37.1505 \\
\hline 4 & 6 & 1 & 8 & 0.0000 & 0.0000 & 73.6461 & 325.2185 \\
\hline 2 & 8 & 3 & 8 & 0.0000 & 0.0000 & 73.7634 & 1026.1586 \\
\hline 1 & 9 & 3 & 8 & 0.0000 & 0.0000 & 74.0325 & 351.4339 \\
\hline 4 & 0 & 3 & 4 & 0.0000 & 0.0000 & 74.0358 & 617.0917 \\
\hline 1 & 7 & 4 & 8 & 0.0000 & 0.0000 & 74.2046 & 116.0688 \\
\hline 4 & 1 & 3 & 8 & 0.0000 & 0.0000 & 74.3725 & 875.0704 \\
\hline 3 & 9 & 0 & 4 & 0.0000 & 0.0000 & 74.5056 & 469.5375 \\
\hline 4 & 5 & 2 & 8 & 0.0000 & 0.0000 & 74.6340 & 528.3604 \\
\hline 1 & 3 & 5 & 8 & 0.0000 & 0.0000 & 74.8097 & 0.0000 \\
\hline 1 & 11 & 1 & 8 & 0.0000 & 0.0000 & 74.9889 & 24.4383 \\
\hline 3 & 8 & 2 & 8 & 0.0000 & 0.0000 & 75.0353 & 84.9668 \\
\hline 2 & 6 & 4 & 8 & 0.0000 & 0.0000 & 75.2799 & 82.8550 \\
\hline 3 & 3 & 4 & 8 & 0.0000 & 0.0000 & 75.2809 & 150.2051 \\
\hline 0 & 4 & 5 & 4 & 0.0000 & 0.0000 & 75.3459 & 0.5766 \\
\hline
\end{tabular}




\section{ACCEPTED MANUSCRIPT}

\begin{tabular}{|c|c|c|c|c|c|c|c|}
\hline 4 & 2 & 3 & 8 & 0.0000 & 0.0000 & 75.3793 & 0.0020 \\
\hline 3 & 9 & 1 & 8 & 0.0000 & 0.0000 & 76.0613 & 161.4098 \\
\hline 4 & 7 & 0 & 4 & 0.0000 & 0.0000 & 76.4483 & 930.6663 \\
\hline 5 & 1 & 0 & 4 & 0.0000 & 0.0000 & 76.6501 & 243.6470 \\
\hline 4 & 3 & 3 & 8 & 0.0000 & 0.0000 & 77.0473 & 888.1843 \\
\hline 1 & 4 & 5 & 8 & 0.0000 & 0.0000 & 77.1473 & 99.7833 \\
\hline 2 & 0 & 5 & 4 & 0.0000 & 0.0000 & 77.2144 & 1014.6197 \\
\hline 0 & 8 & 4 & 4 & 0.0000 & 0.0000 & 77.4129 & 635.8745 \\
\hline 2 & 1 & 5 & 8 & 0.0000 & 0.0000 & 77.5464 & 585.2836 \\
\hline 3 & 4 & 4 & 8 & 0.0000 & 0.0000 & 77.6139 & 77.4292 \\
\hline 5 & 2 & 0 & 4 & 0.0000 & 0.0000 & 77.6470 & 24.0890 \\
\hline 3 & 7 & 3 & 8 & 0.0000 & 0.0000 & 77.7761 & 139.5154 \\
\hline 0 & 11 & 2 & 4 & 0.0000 & 0.0000 & 77.8332 & 25.3627 \\
\hline 5 & 0 & 1 & 4 & 0.0000 & 0.0000 & 77.8606 & 13.4447 \\
\hline 4 & 7 & 1 & 8 & 0.0000 & 0.0000 & 77.9912 & 78.7823 \\
\hline 2 & 10 & 2 & 8 & 0.0000 & 0.0000 & 78.0328 & 336.6565 \\
\hline 5 & 1 & 1 & 8 & 0.0000 & 0.0000 & 78.1918 & 76.2758 \\
\hline 4 & 6 & 2 & 8 & 0.0000 & 0.0000 & 78.3002 & 0.5663 \\
\hline 0 & 5 & 5 & 4 & 0.0000 & 0.0000 & 78.3406 & 0.0471 \\
\hline 2 & 2 & 5 & 8 & 0.0000 & 0.0000 & 78.5399 & 0.0001 \\
\hline 0 & 10 & 3 & 4 & 0.0000 & 0.0000 & 78.5686 & 0.0208 \\
\hline 2 & 11 & 0 & 4 & 0.0000 & 0.0000 & 78.8339 & 26.1129 \\
\hline 5 & 2 & 1 & 8 & 0.0000 & 0.0000 & 79.1830 & 380.6018 \\
\hline 1 & 8 & 4 & 8 & 0.0000 & 0.0000 & 79.1997 & 377.9432 \\
\hline 0 & 12 & 0 & 2 & 0.0000 & 0.0000 & 79.2950 & 78.8172 \\
\hline 5 & 3 & 0 & 4 & 0.0000 & 0.0000 & 79.3003 & 70.4852 \\
\hline 4 & 4 & 3 & 8 & 0.0000 & 0.0000 & 79.3642 & 54.1716 \\
\hline
\end{tabular}


$\begin{array}{llllllll}2 & 9 & 3 & 8 & 0.0000 & 0.0000 & 79.4276 & 128.1648\end{array}$

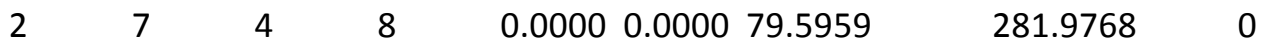

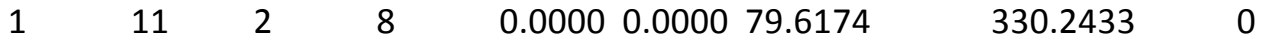

